\title{
Holocene Alpine Soils in Gneissic Cirque Deposits, Colorado Front Range
}

\section{U.S. GEOLOGICAL SURVEY BULLETIN 1590-E}

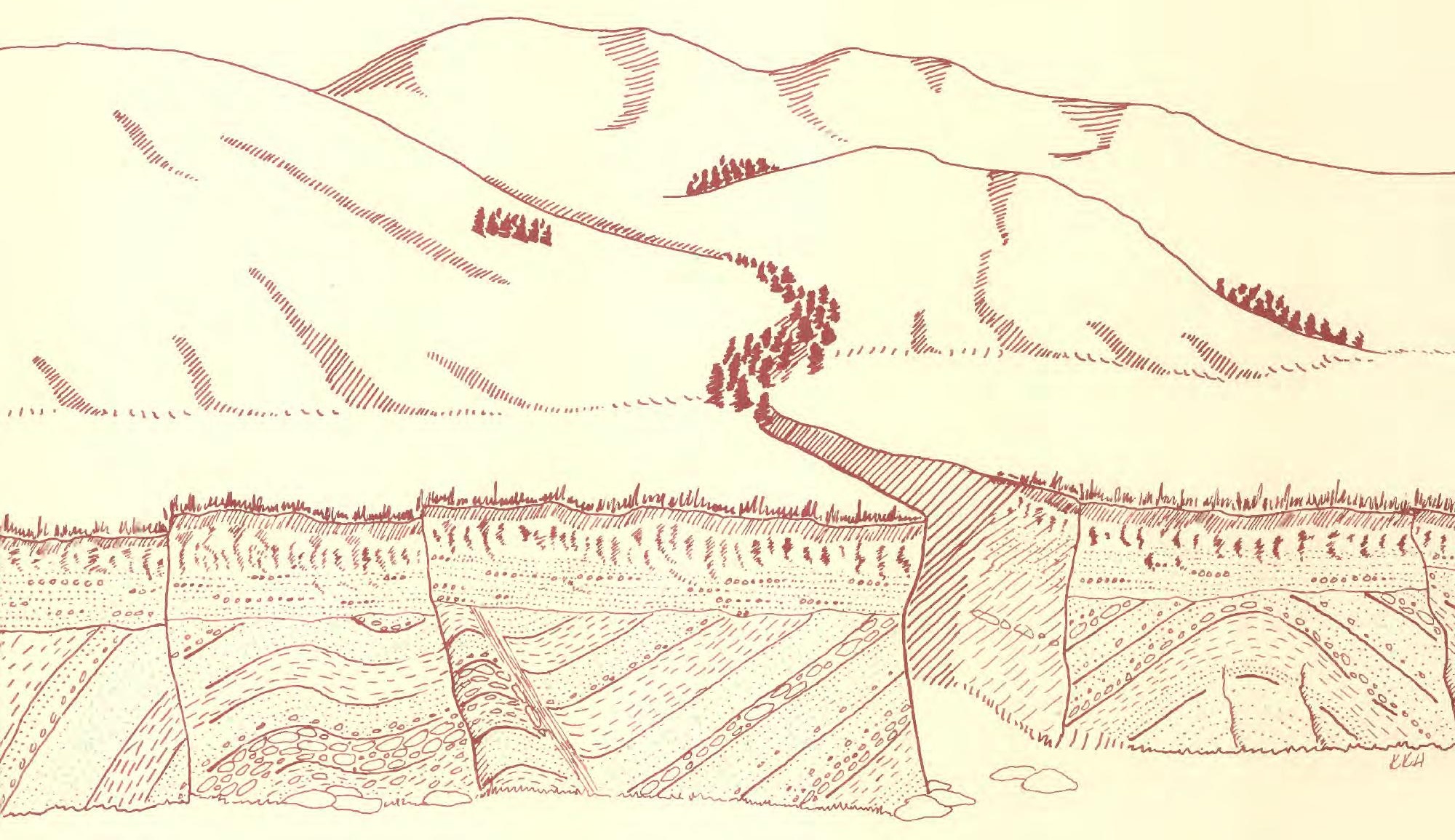



Chapter E

\section{Holocene Alpine Soils in Gneissic Cirque Deposits, Colorado Front Range}

By P.W. BIRKELAND, R.M. BURKE, and R.R. SHROBA 


\title{
DEPARTMENT OF THE INTERIOR \\ DONALD PAUL HODEL, Secretary
}

\author{
U.S. GEOLOGICAL SURVEY
}

Dallas L. Peck, Director

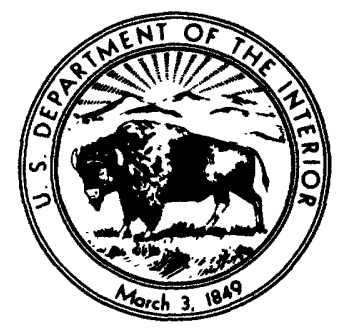

For sale by the

Books and Open-File Reports Section

U.S. Geological Survey

Federal Center, Box 25425

Denver, CO 80225

\section{Library of Congress Cataloging-in-Publication Data}

Birkeland, Peter W.

Holocene alpine soils in gneissic cirque deposits,

Colorado Front Range.

(U.S. Geological Survey Bulletin 1590-E)

(Soil chronosequences in the Western United States)

Bibliography

1. Mountain soils-Front Range (Colorado and Wyoming).

2. Mountain soils-Colorado. 3. Soil formation-Front

Range (Colorado and Wyoming). 4. Soil formation-

Colorado. 5. Soil chronosequences-Front Range

(Colorado and Wyoming). 6. Soil chronosequences-

Colorado. 7. Gneiss-Front Range (Colorado and

Wyoming). 8. Gneiss-Colorado. 9. Geology-Front

Range (Colorado and Wyoming). 10. Geology-Colorado.

11. Geology, Stratigraphic_Recent. I. Burke, R.M. II.

Shroba, R.R. III. Title. IV. Series. V. Series: Soil

chronosequences in the Western United States.

QE75.B9 No. 1590-E $557.3 \mathrm{~s}$

$87-600223$

[S599.C6]

[553.6'09788] 


\section{FOREWORD}

This series of reports, "Soil Chronosequences in the Western United States," attempts to integrate studies of different earth-science disciplines, including pedology, geomorphology, stratigraphy, and Quaternary geology in general. Each discipline provides information important to the others. From geomorphic relations we can determine the relative ages of deposits and soils; from stratigraphy we can place age constraints on the soils. Field investigations and mineralogic and sedimentologic studies provide information on the nature and types of deposits in which soils form. As a result of our work, we have estimated rates of soil formation, inferred processes of soil formation from trends in soil development with increasing age, and obtained information on the types of weathering that occur in various areas. In return, soil development and soil genesis have provided data on the age of landforms, the timing and duration of sedimentation, and, in some cases, the history of climatic fluctuations.

Between 1978 and 1983, a coordinated and systematic study was conducted on soil development in different types of geologic deposits in the Western United States. The goals of this project, led by the late D.E. Marchand and subsequently by M.N. Machette, were to learn whether rates of chemical, physical, and mineralogic transformations could be determined from soil chronosequences; how these rates vary in different mineralogic and climatic environments; and how accurately soils can be used for such problems as estimating the ages of deposits, periods of landscape stability, and timing of fault movements. This series of reports presents data from several soil chronosequences of that project.

More than 100 analyses on more than 1,000 samples were performed on soils collected in the Western United States. Some results have appeared in various books, journals, and maps (for example, Harden and Marchand, 1977, 1980; Burke and Birkeland, 1979; Dethier and Bethel, 1981; Marchand and Allwardt, 1981; Meixner and Singer, 1981; Busacca, 1982; Harden, 1982a,b; Harden and Taylor, 1983; Machette, 1983; Machette and Steven, 1983; Busacca and others, 1984; Machette and others, 1984; Reheis, 1984). In the reports in this series, the basic field information, geologic backsround, and analytical data are presented for each chronosequence, as well as some results additional to the previous publications.

One of the most significant aspects of these chronosequence studies is that in every study area, many soil parameters change systematically over time, or with the age of deposits. As Deming (1943) emphasized, it is this recurrence of correlation in such different conditions that is most significant to geologic and pedologic studies. In relatively moist areas, such as coastal and central California, such soil properties as percent clay or reddening of soil colors change most systematically over time. In more arid regions, such as in the Bighorn basin of Wyoming, calcium carbonate and gypsum contents best reflect relative ages of the deposits. A few parameters-for example, elemental composition of sands or clays-appear to be comparable between areas so diverse in climatic setting.

Numeric age control has enabled us to estimate rates of soil development. In some places, we have been able to compare rates between different areas. For example, in central California, rates of clay accumulation were found to be most rapid during the initial stages of soil development; the rates declined with increasing age. The straightest lines for regression were on a $\log -\log$ scale. In coastal California, rates of clay accumulation appeared to be much higher than in central California. This difference in rates could be due to parent material (the coastal soils that we studied formed on reworked shale and sandstone, whereas central California soils were developed in granitic alluvium), and (or) the differences in rates could be due to eolian additions of clay. In the Bighorn basin of Wyoming, rates of clay accumulation, as well as most other soil properties, increased linearly over time, with no apparent decrease in initial rates.

The data we present here suggest many opportunities for further interpretation. For example, we may learn how climate, vegetation, and mineralogy affect the rates of clay formation or organic-matter accumulation. In some study areas, we present data for rare-earth elements, which could be used to examine how each element reacts in different weathering environments. These examples are only a fraction of the possible future studies that could be conducted on the data presented here.

J.W. Harden

Editor 



\title{
CONTENTS
}

\author{
Foreword III \\ Abstract E1 \\ Introduction E1 \\ Environmental factors E2 \\ Parent materials E2 \\ Stratigraphic units and geochronology E3 \\ Climate E3 \\ Vegetation E6 \\ Topography E6 \\ Soil nomenclature E6 \\ Site selection and sampling procedures $\mathbf{E 6}$ \\ Definitions of the chemical extracts E7 \\ Trends in the field and laboratory data for the soil chronosequence E7 \\ Post-Gannet Peak soil E7 \\ Post-Audubon soil E7 \\ Post-Triple Lakes soil E8 \\ Post-Satanta Peak soils E8 \\ Summary of soil-profile characteristics E8 \\ Comparison with previous work E9 \\ Trends in soil development indices with time E10 \\ Definitions E10 \\ Results E10 \\ Conclusions E10 \\ References cited E13 \\ Supplementary tables E15 \\ FIGURES \\ 1. Generalized map of study area $\mathbf{E 2}$ \\ 2. Aerial photograph of Arapaho cirque showing glacial \\ and periglacial deposits and study sites E4 \\ 3. Plot of profile-development indices versus \\ approximate age of soil parent materials E11 \\ 4. Plot of color indices versus approximate age of \\ soil parent materials E12

\section{TABLES} \\ 1. Age control for the glacial and periglacial deposits \\ in Arapaho cirque $\mathbf{E 5}$ \\ 2. Rock-weathering data $\mathbf{E 5}$ \\ 3. Precipitation and temperature data for station D-1, \\ Niwot Ridge, Colorado E6 \\ 4. Values for soil-profile and color indices of the soils E11 \\ 5. Regression-equation data for the soil-profile and \\ color indices E12 \\ 6. Selected statistical measures for the soil-profile and \\ color indices for the post-Satanta Peak soils E12 \\ SUPPLEMENTARY TABLES \\ 1. Field descriptions E16 \\ 2. Physical properties $\mathbf{E 1 7}$ \\ 3. Extractive chemical analyses $\mathbf{E 1 8}$ \\ 4. Clay mineralogy E19 \\ 5. Total chemical analyses of the soils determined by \\ X-ray fluorescence spectroscopy E20 \\ 6. Total chemical analyses of the soils determined by instrumental \\ neutron activation E21
}




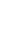




\title{
Holocene Alpine Soils in Gneissic Cirque Deposits, Colorado Front Range
}

\author{
By P.W. Birkeland, ${ }^{1}$ R.M. Burke, ${ }^{2}$ and R.R. Shroba
}

\section{ABSTRACT}

Study of a chronosequence of alpine soils in the Colorado Front Range suggests a moderately rapid rate of soil formation during the Holocene. Soil parent materials in this study include glacial and periglacial deposits named Gannett Peak (100-350 yr), Audub on $(950-2,400 \mathrm{yr})$, Triple Lakes $(3,000-5,200 \mathrm{yr})$, and Satanta Peak (10,000-12,000 yr). Soil morphology and chem istry vary in a predic table manner with increasing age. The post-Gannett Peak soil has a very thin, weakly developed A/Cox profile; the post-Audubon soil has a thicker, better developed $\mathrm{A} / \mathrm{AC} / \mathrm{Cox}$ profile; the post-Triple Lakes soil has an $\mathrm{A} / \mathrm{Bw} / \mathrm{Cox}$ profile; and post-Satanta Peak soils have $\mathrm{A} / \mathrm{Bw}$ (or $\mathrm{Bt}$ )/Cox profiles. The two youngest soils are classified as Pergelic Cryorthents, the post-Triple Lakes soil is either a Pergelic Cryumbrept or Pergelic Cryoboroll. The best developed of the post-Satanta Peak soils are either Argic Pergelic Cryoborolls or Pergelic Cryoboralfs. Airborne dust seems to have had an influence on the texture of the surface horizons of the post-Triple Lakes and post-Satanta Peak soils, and may account for some of the translocated clay in the Bt horiz ons of the post-Sa tanta Peak soils.

Soil development trends with increasing age include increasing amounts of organic carbon, total nitrogen, organic-bound phosphorus, clay, extractable iron and aluminum, and higher cation exchange capacity. Loss of acid-extractable calcium-bound phosphorus with time suggests a moderately intense leaching environment. Calcium is the dominant exchangeable cation in all soils, and magnesium is present as an exchangeable cation only in the postTriple Lakes and post-Satanta Peak soils. The clay mineralogy is difficult to interpret, but the main trends with time are the depletion and (or) dilution of kaolinite, smectite, and mica, and the formation and (or) addition of 1-1.4 nm mixed-layer clays.

Both the field and laboratory data suggest a moderately rapid rate of development for soils in the alpine of the Colorado Front Range compared to those at lower elevations, in spite of the cold climate.

\footnotetext{
${ }^{1}$ University of Colorado, Boulder, CO 80309.

${ }^{2}$ Humboldt State University, Arcata, CA 95521.
}

\section{INTRODUCTION}

Soil formation is moderately rapid in the higher mountain ranges of the western United States, as compared to those at lower elevations. One such area is the Colorado Front Range (Shroba and Birkeland, 1983). The main objective of this report is to document soil development in the alpine of the Colorado Front Range by utilizing soil morphology; physical, chemical, and mineralogical data; and various soil development indices. Other objectives are (1) to compare our age assignments and soil-horizon designations with those of previous workers, (2) to determine the variability and reproducibility of the field and laboratory data for the post-Satanta Peak soils, and (3) to evaluate the usefulness of some color and soil-profile indices as an indication of soil age in an alpine environment.

The soils studied are in Arapaho cirque, a small alpine basin in the Indian Peaks area of the Colorado Front Range (fig. 1). Arapaho Glacier, the largest glacier in Colorado, lies against the headwall in the western part of the cirque. The cirque walls are steep and rise about 150 to $350 \mathrm{~m}$. The soils have formed from Holocene and very latest Pleistocene deposits downvalley of the glacier at altitudes between 3,450 and $3,700 \mathrm{~m}$.

Mahaney (1974) did the initial quantitative work on the soils in Arapaho cirque and vicinity. Subsequent, detailed soil investigations have been conducted in the study area and (or) in nearby cirques and valleys by Shroba (1977; Shroba and Birkeland, 1983), Benedict $(1981,1985)$, Burns (1980), Dixon (1983, 1986), Albino (1984), and Litaor (1987). This report provides additional morphological, chemical, and mineralogical data for the soils in Arapaho cirque.

Acknowledgments.-J.W. Harden helped describe the soils in the field. Discussions with numerous people have been helpful to us over the many years that we have worked in the cirques of the Colorado Front Range. These people include J.T. Andrews, J.B. Benedict, S.F. Burns, P.E. Carrara, T. Carroll, D.R. Crandell, P.T. Davis, W.C. Mahaney, and D.R. Mullineaux. R. Kihl of the University of Colorado analyzed some of the samples from soil CO8. R. Bruce and D. Geary assisted in the field, and students in 
Birkeland's 1982 soils class at the University of Colorado helped calculate some of the indices. This project was funded by the U.S. Geological Survey Soil Correlation and Dating Project, coordinated by the late D.E. Marchand and M.N. Machette. We are grateful to J.B. Benedict, A.J. Busacea, and P.E. Carrara for their thoughtful reviews of this manuscript.

\section{ENVIRONMENTAL FACTORS}

Pedologists recognize five main factors that define the state of the soil system (Jenny, 1980).
These are parent material, time (duration of soil development), climate, vegetation, and topography.

\section{Parent Materials}

The deposits from which the soils are formed include till and rock-glacier debris. These deposits have a high boulder content (commonly greater than $\mathbf{5 0}$ percent by volume) and a sandy matrix. Deposits older than about 1,000 years usually have a loamy surface layer that makes up the upper part of the soil. This material has been considered to be eolian in origin (Benedict, 1973, 1981; Mahaney, 1974; Birkeland and
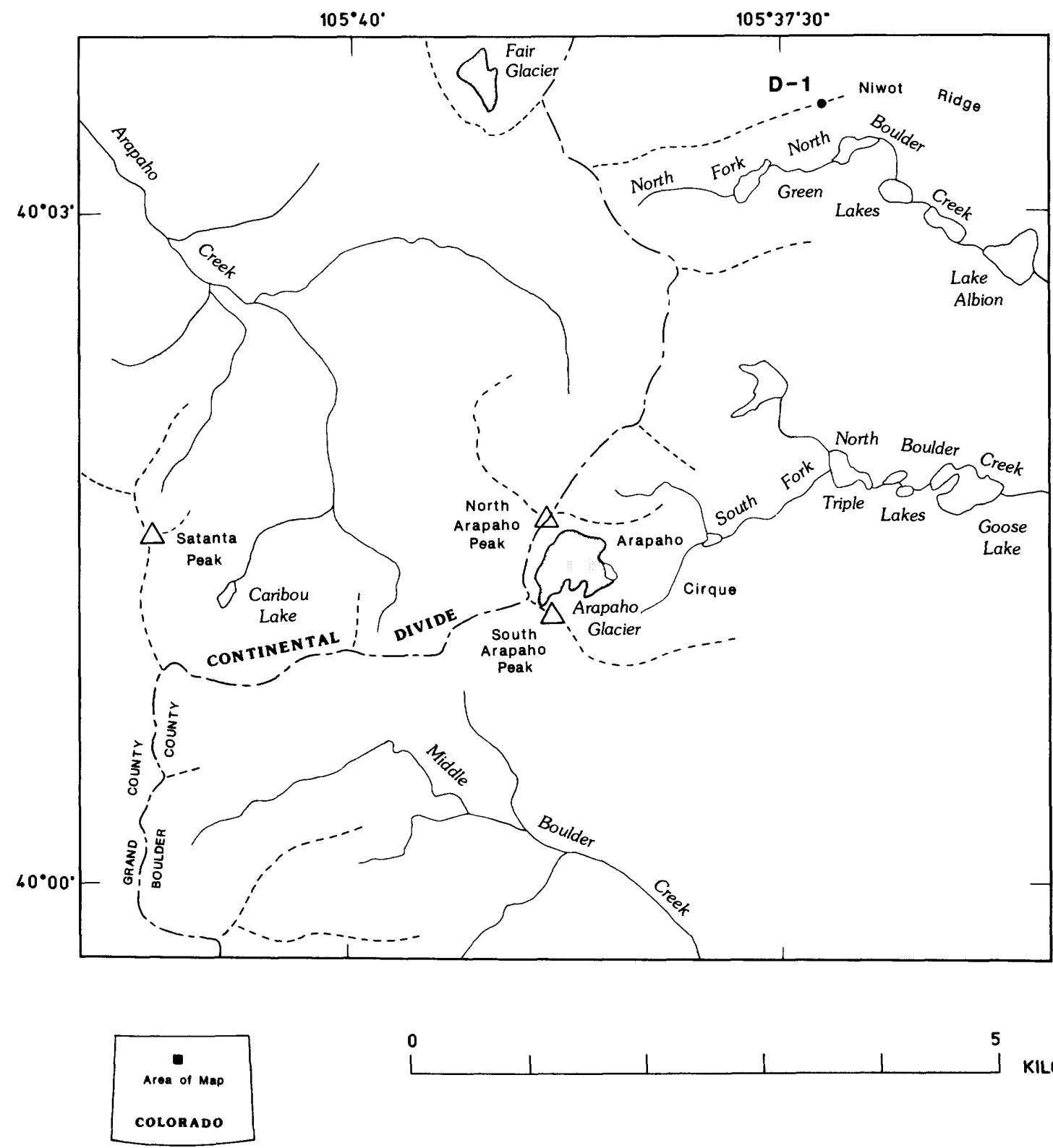

KILOMETERS

Figure 1. Generalized map of study area. Short dashed lines indicate prominent ridge crests; triangles denote peaks. Location of meteorological station D-1 is approximate. Grid pattern indicates extent of glaciers. 
Shroba, 1974; Shroba, 1977; Burns, 1980; Thorn and Darmody, 1980, 1985; Burns and Tonkin, 1982; Shroba and Birkeland, 1983; and Litaor, 1987). Dixon (1983, 1986) also recognized eolian material and suggested that at least some of the fine-grained material in the upper part of the soil is due to weathering. In some places the fine-grained material is gravel free, whereas in other places it contains gravel. This gravel may have been derived from the underlying material.

The bedrock in Arapaho cirque is Precambrian biotite gneiss with lenses of granodiorite. The biotite gneiss is composed of biotite, quartz, and plagioclase, along with lesser amounts of sillimanite, microcline, garnet, and cordierite (Pearson, 1980). The granodiorite consists chiefly of plagioclase, quartz, biotite, and potassium feldspar (Gable, 1980). We assume that the sand and finer fractions of the glacial and periglacial deposits, as well as the locally derived eolian material, are made up primarily of these minerals. However, if the fine-grained surface layers have been enriched by eolian silt and clay from distant sources, the mineralogy of these fine-grained layers may differ from that of the same size fractions of tills and rock-glacier deposits that are free of eolian sediment.

\section{Stratigraphic Units and Geochronology}

The glacial and periglacial deposits in Arapaho cirque (fig. 2) are of Holocene and very latest Pleistocene age (table 1); however, there are differences of opinion regarding the ages of some of the older deposits ${ }^{3}$. Benedict (1967, 1968, 1973, and 1981) and Benedict and Benedict (1984) have done the most detailed mapping and dating of the deposits in Arapaho cirque. Other important contributions have been made by White (1971), Madole (1972), Mahaney (1974), Birkeland and Shroba (1974), Reheis (1975), Davis and Waterman (1979), Davis and others (1979, 1984), and Davis (1982). Meierding and Birkeland (1980) and Burke and Birkeland (1983) have reviewed the previous work in Arapaho cirque and in other cirques in the western United States. The ages of the deposits in these cirques have been estimated from radiocarbon dates and relative-age data such as lichenometry, rock weathering, and soils. All of those who have worked in Arapaho cirque (cited above) agree that the youngest deposit is a till about 100 to 350 years old, based on historical records and lichenometry. It is equivalent to the Gannett Peak deposits identified throughout the Rocky Mountains (Richmond, 1965), therefore the term Gannett Peak is used here rather than Arapaho Peak, a term introduced by Benedict (1973). Downvalley from the Gannett Peak deposits are rock-glacier deposits that all workers agree are of Audubon age. These deposits are about 950 to 2,400 years old, based on radiocarbon dates and lichenometry. Immediately in front of the

${ }^{3}$ All of the Quaternary deposits referred to in this report are informal. They are considered allostratigraphic units according to the North American Commission on Stratigraphic Nomenclature (1983).
Audubon deposits is an older rock-glacier deposit designated Triple Lakes by Benedict (1973); Triple Lakes deposits are probably about 3,000 to 5,200 years old, based on radiocarbon dates on younger and older deposits and on lichenometry. The only other deposit in the cirque of interest in this study is till immediately downvalley from the Triple Lakes rockglacier deposit. The age of the till (the Satanta Peak till deposits of this report) is not agreed on by all workers (Meierding and Birkeland, 1980; Burke and Birkeland, 1983). Benedict (1973) relied mainly on minimum limiting radiocarbon dates (table 1) to suggest that the till is of Triple Lakes age.

There are two reasons for suggesting that the till downvalley of the Triple Lakes rock-glacier deposit is Satanta Peak rather than Triple Lakes as defined by Benedict $(1973,1981)$. First, five radiocarbon dates on detrital organic matter in sediment from a lake behind the inner moraine (just west of site $\mathrm{CO} 4$ in fig. 2) range from 4,730 to $10,410 \mathrm{yr}$ B.P. (see dates of Davis in table 1). Considering that none of the dates are on basal sediment, the date of $10,410 \mathrm{yr}$ B.P. is considered to be a minimum date for the age of the till.

The second reason for suggesting a Satanta Peak age for the till is based on our rock-weathering studies. Of interest here are data for the Triple Lakes rock-glacier deposit and the till immediately downvalley from it (table 2). The rock-weathering data for biotite gneiss are considered to be better indicators of differences in weathering than are those for granodiorite, because granodiorite is not abundant in these deposits and fewer observations were made for granodiorite than for gneiss. Although there are minor differences in the percentage of both weathered and pitted clasts between deposits, pit depths are markedly different between the two deposits. We attribute these differences in weathering to a difference in the ages of the two deposits. We suggest that the till is much older than the rock-glacier deposit, although some of the apparent differences in age could be due in part to the greater length of time between the deposition and stabilization of surface boulders on the rock-glacier deposit than for those on the till.

The best evidence for assessing the age of the till downvalley of the Triple Lakes rock-glacier deposit is the $10,410 \mathrm{yr}$ B.P. radiocarbon date, mentioned above, on lake sediment that postdates the till. Because this date is within the estimated age range of the Satanta Peak till of Benedict (1985) (10,000-12,000 $\mathrm{yr})$, we consider the oldest till that we studied to be Satanta Peak.

\section{Climate}

The climate of Arapaho cirque can be approximated by meteorological data from station D-1 (table 3 ), which is in the alpine tundra on Niwot Ridge, about $4 \mathrm{~km}$ to the north (fig. 1). Mean annual precipitation for 1965 through 1970 was $102 \mathrm{~cm}$. Precipitation from October to May is mostly snow. Winter snow is light and dry and can be readily blown from ridges, such as the sites selected for this study. In contrast, late spring snow is heavier and wetter, and 
much of the moisture released by melting infiltrates the soil. The result is that not all of the precipitation is distributed evenly on the landscape. The summer precipitation in the cirque is not well known. A threeyear study during all or part of the summers of 1971 through 1973 indicated that precipitation ranged from 16.5 to $31.6 \mathrm{~cm}$ (Johnson, 1979). The study area is cold, with a mean annual air temperature of $-3.8^{\circ} \mathrm{C}$ and a mean frost-free period of 47 days. The mean annual soil temperature at a depth of $30 \mathrm{~cm}$ at station $\mathrm{D}-1$ is $-1.1{ }^{\circ} \mathrm{C}$ (Marr and others, 1968; Burns, 1980). Burns (1980) collected soil-temperature data from eight alpine sites on Niwot Ridge east of station D-1; the mean annual soil temperature at these sites ranged from 0.9 to $3.4^{\circ} \mathrm{C}$. Depending upon local conditions, the soil-temperature regime varies from cryic to

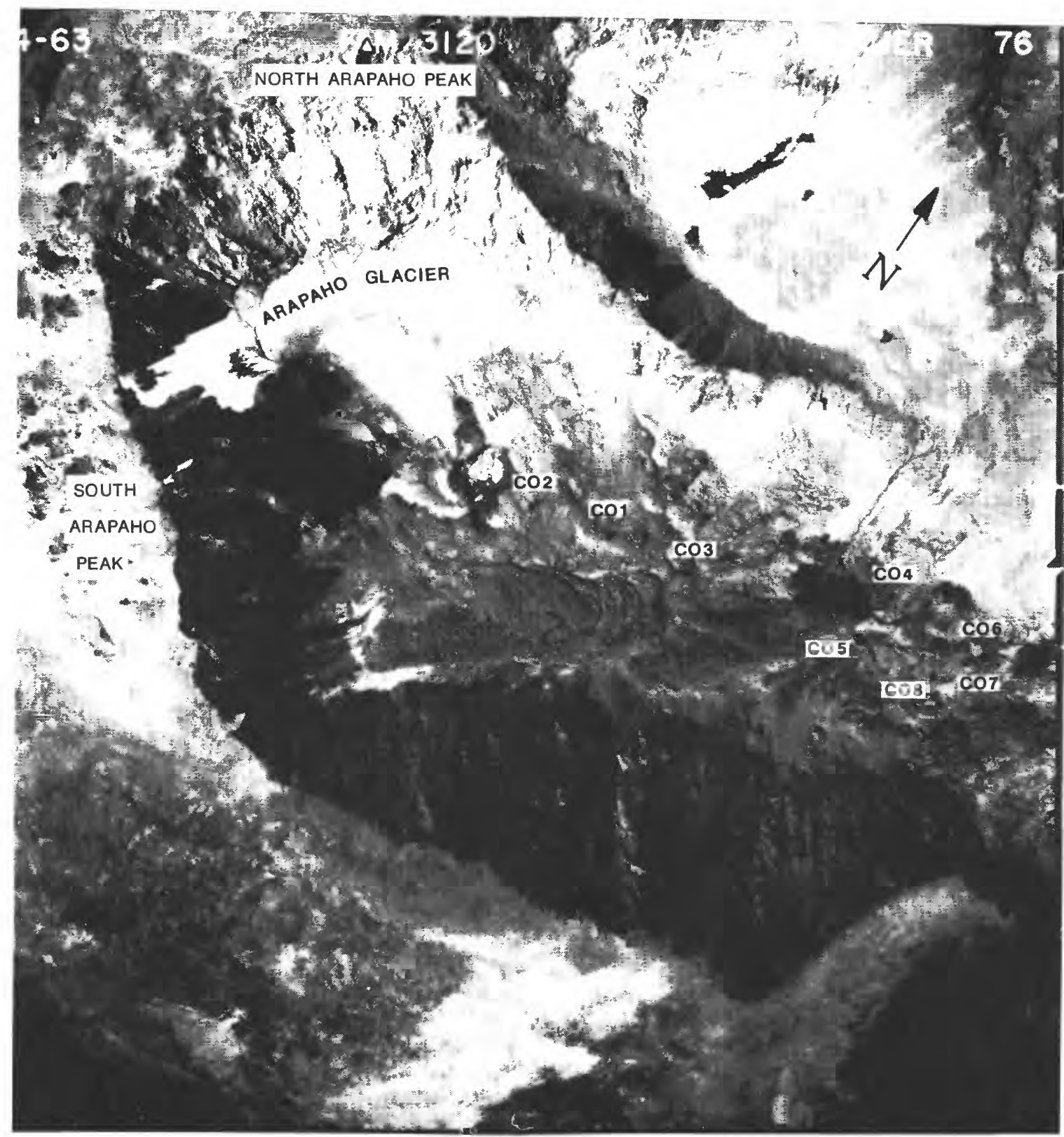

0

1 KILOMETER

Figure 2. Aerial photograph of Arapaho cirque showing glacial and periglacial deposits and study sites (CO1 to CO8). Deposits at and near study sites, from youngest to oldest, include Gannett Peak till deposits (CO2), Audubon rockglacier deposits (CO1), Triple Lakes rock- glacier deposit (CO3), and Satanta Peak till deposits ( $\mathrm{CO} 4, \mathrm{CO} 5, \mathrm{CO}, \mathrm{CO}$, and $\mathrm{CO} 8$ ). Lake cored by Davis (1982; Davis and others, 1984; Davis, 1987) is just west of site CO4. Source of aerial photograph is unknown. 
Table 1. Age control for the glacial and periglacial deposits in Arapaho cirque

[Historical records (H) provide only a minimum age for youngest Gannett Peak till deposits (Benedict, 1968). Lichenometry (L) probably provides only minimum ages, especially for deposits greater than about 2,500 yr old (Benedict, 1985, fig. 43). Radiocarbon ages (R), in years before present, for Audubon rock-glacier deposits are on organic matter from ablation surfaces in ice of rock glacier; those for Satanta Peak till deposits are on organic matter in deposits that are younger than the till deposits, therefore, they provide only minimum ages of the till deposits. Estimated age ranges are from Benedict (1985)]

\begin{tabular}{|c|c|c|c|c|c|}
\hline \multicolumn{2}{|c|}{ Deposit } & \multirow{2}{*}{$\begin{array}{l}\text { Estimated } \\
\text { age range, } \\
\text { in yr B.P., } \\
\text { for deposits } \\
\text { in this } \\
\text { report }\end{array}$} & \multicolumn{3}{|c|}{ Age control for deposits } \\
\hline Benedict (1973) & This report & & $\begin{array}{l}\text { Dating } \\
\text { method }\end{array}$ & $\begin{array}{c}\text { Age } \\
(y r \text { B.P.) }\end{array}$ & References \\
\hline $\begin{array}{c}\text { Arapaho Peak } \\
\text { deposits }\end{array}$ & $\begin{array}{l}\text { Gannett Peak } \\
\text { till deposits }\end{array}$ & $100-350$ & $\mathrm{H}, \mathrm{L}$ & $100-250$ & Benedict (1973) \\
\hline $\begin{array}{l}\text { Audubon } \\
\text { deposits }\end{array}$ & $\begin{array}{l}\text { Audubon } \\
\text { rock-glacier } \\
\text { deposits }\end{array}$ & $950-2,400$ & $\begin{array}{l}\mathrm{L} \\
\mathrm{R} \\
\mathrm{R}\end{array}$ & $\begin{aligned} & 950-1,850 \\
& 955 \pm 95 \\
& 1,000 \pm 90\end{aligned}$ & $\begin{array}{l}\text { Do. } \\
\text { Do. } \\
\text { Do. }\end{array}$ \\
\hline $\begin{array}{l}\text { Triple Lakes } \\
\text { deposits }\end{array}$ & $\begin{array}{l}\text { Triple Lakes } \\
\text { rock-glacier } \\
\text { deposits }\end{array}$ & $3,000-5,200$ & $\mathrm{~L}$ & 3,150 & Do. \\
\hline $\begin{array}{l}\text { Triple Lakes } \\
\text { deposits }\end{array}$ & $\begin{array}{l}\text { Satanta Peak } \\
\text { till deposits }\end{array}$ & $10,000-12,000$ & $\begin{array}{l}\mathrm{L} \\
\mathrm{R} \\
\mathrm{R} \\
\mathrm{R} \\
\mathrm{R} \\
\mathrm{R} \\
\mathrm{R} \\
\mathrm{R} \\
\mathrm{R} \\
\mathrm{R}\end{array}$ & $\begin{array}{l}2,850 \\
2,360 \pm 120 \\
2,560 \pm 100 \\
3,865 \pm 100 \\
4,485 \pm 100 \\
4,730 \pm 200 \\
5,400 \pm 240 \\
6,430 \pm 70 \\
9,915 \pm 380 \\
10,410 \pm 520\end{array}$ & $\begin{array}{l}\text { Do. } \\
\text { Do. } \\
\text { Do. } \\
\text { Do. } \\
\text { Do. } \\
\text { Davis (1982) } \\
\text { Do. } \\
\text { Do. } \\
\text { Davis (1987) } \\
\text { Do. }\end{array}$ \\
\hline
\end{tabular}

\section{Table 2. Rock-weathering data}

[Rock-weathering data features are defined in Burke and Birkeland (1979); underscored data collected by R.R. Shroba, other data collected by P.W. Birkeland. Rock-weathering sites are shown on figure 2. Values in parentheses refer to number of measurements made. nd, no data]

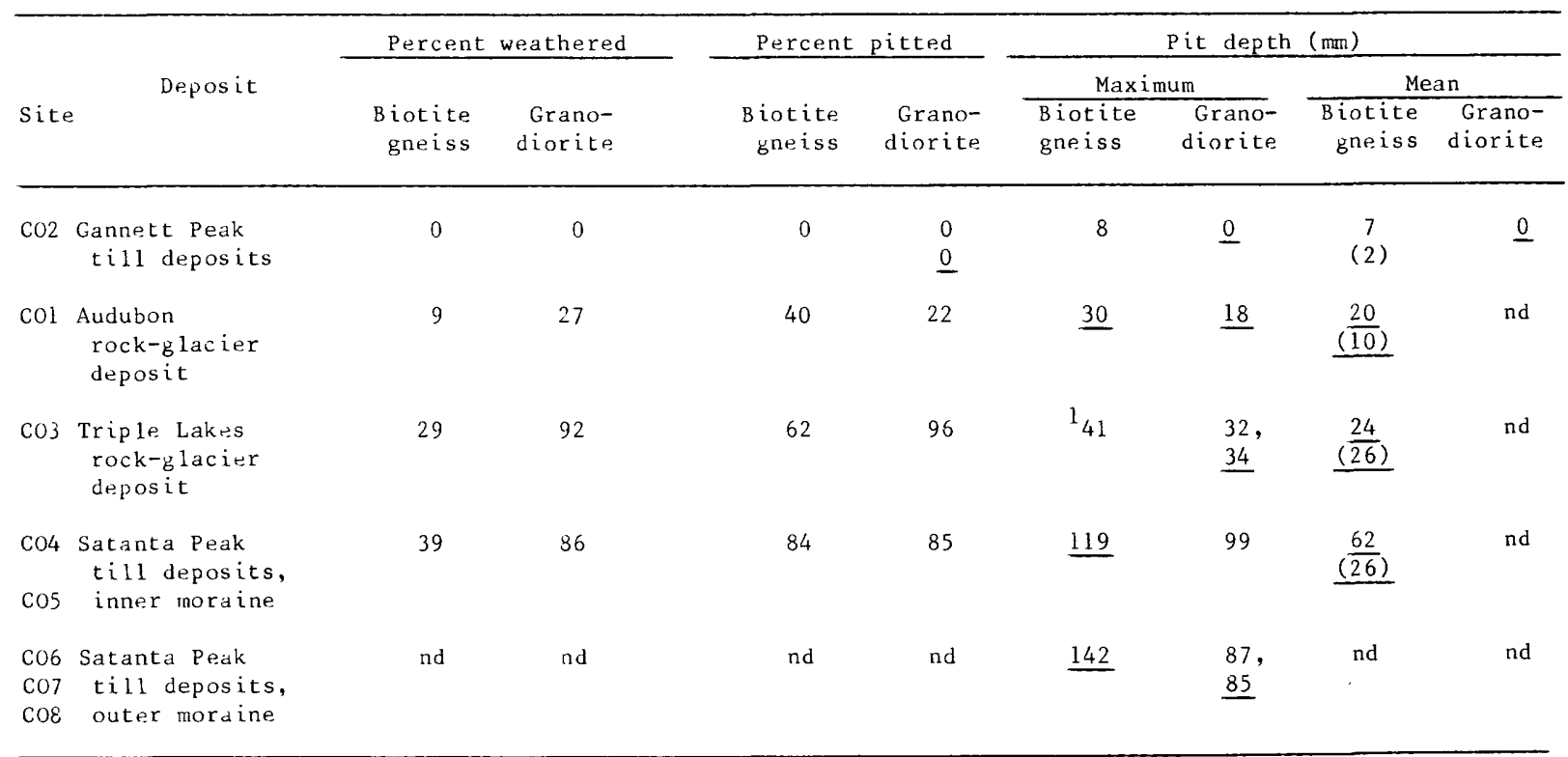

\footnotetext{
${ }^{1}$ Two pits that may not be entirely due to weathering were 44 and $73 \mathrm{~cm}$ deep.
} 


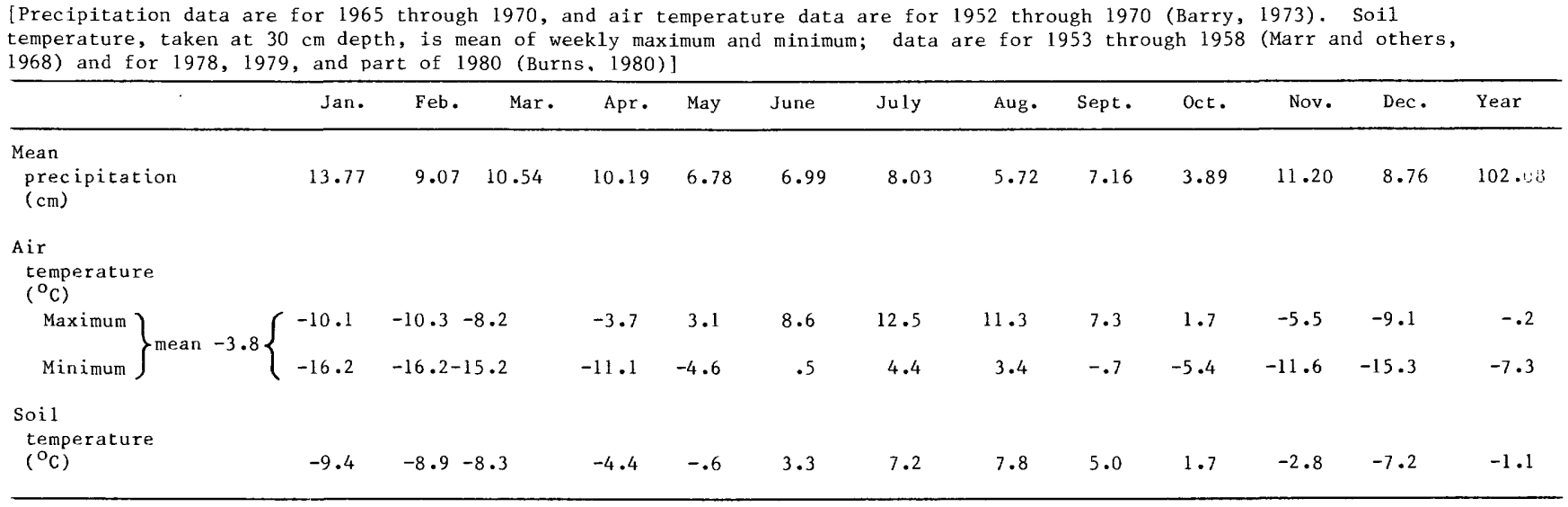

pergelic (Soil Survey Staff, 1975). It is likely that the soils in this study have a pergelic soil-temperature regime. The soil-temperature data in table 3 suggest that the soils are frozen for about seven months a year.

\section{Vegetation}

Although the vegetation in Arapaho cirque has not been mapped or studied in detail, the plants in the cirque consist primarily of grasses, herbs, sedges, and shrubs (Marr, 1961). Vegetation mapping by Komarkova and Webber (1978) on Niwot Ridge suggests that the alpine plant community type in well-drained areas on the Satanta Peak moraines is alliance Kobresia-Caricion rupestris and association EritrichoDryadetum octopetalae. Krummholtz forms of Engelmann spruce and subalpine fir are present on the distal slope of the outer Satanta Peak moraine; however, it is not known if they ever grew at any of the study sites on the Satanta Peak moraines.

The proportion of the non-bouldery ground surface covered by tundra vegetation varies with the age of the deposit. In non-bouldery areas vegetation covers about 25 percent or less of the Gannett Peak deposits, 25 percent of the Audubon deposits, 75 percent of the Triple Lakes deposit, and greater than 75 percent of the Satanta Peak deposits.

\section{Topography}

The topographic setting of soil-sampling sites is important in chronosequence studies. The desired strategy in these studies is to select sites where the soil has been forming continuously since the parent material was deposited. Ideally, a site should be relatively unaffected by erosion or by deposition from nearby cirque walls. The sites in this study are on relatively flat $(<2$ percent slopes), broad ridge crests, or gentle slopes where erosion is thought to be minimal. The sites are located far from cirque walls. Because there commonly is a topographic low between the site and the nearest cirque wall, deposition of cirque-wall debris at these sites is unlikely. Eolian processes are probably the only mechanism by which younger sediment could be transported to the sites following the deposition of the till or rock-glacier debris. Consequently, the properties of each of the soils of this chronosequence should approximate the sum total of pedogenesis since the deposition of the parent material(s) at each of the sites.

\section{SOIL NOMENCLATURE}

The soils in this study were described according to the procedures of the Soil Conservation Service (Soil Survey Staff, 1975). Soil-horizon nomenclature is that of the Soil Conservation Service (Soil Survey Staff, 1951; Guthrie and Witty, 1982) combined with the C-horizon nomenclature of Birkeland (1984a). For $\mathrm{C}$ horizons, Cox is slightly oxidized material that does not meet the criteria for a cambic (color) B horizon, and $\mathrm{Cu}$ is unweathered parent material. The diagnostic horizons are those defined by the Soil Survey Staff (1975) for classification purposes.

The soil names in this report are informal. They are formed by adding the prefix "post" to the name for the soil parent material. For example, the soil formed from till of the Gannett Peak advance is termed the post-Gannett Peak soil.

\section{SITE SELECTION AND SAMPLING PROCEDURES}

Sites were selected in order to maximize soil development. Because so little of the Gannett Peak moraine has any alpine plants, the soil was collected on the outermost moraine where a small cluster of plants was growing. Rock-glacier deposits are difficult for soil sampling because stable sites on ridges are not common, therefore, there were few suitable sites on the Audubon and Triple Lakes rockglacier deposits. In contrast, there are many stable, well-vegetated sites on the crests of Satanta Peak moraines. We described and sampled several soil profiles from the inner and outer Satanta Peak moraines in order to determine (1) if there were any 
differences between the soils on the same moraine, (2) if there were any pedological differences between moraines that correspond with differences in relative age, and (3) the reproducibility of the field and laboratory data.

Channel samples were collected for each soil horizon. The samples were screened in the field; material larger than $3 \mathrm{~mm}$ in diameter was discarded. Prior to laboratory analyses, the samples were passed through a 2-mm screen. All of the analyses, as well as air-dry color, were performed on material less than 2 $\mathrm{mm}$ in size.

\section{DEFINITIONS OF THE CHEMICAL EXTRACTS}

Chemical extracts of iron, aluminum, and phosphorus commonly exhibit systematic pedological trends with time (see Birkeland, 1984a, for examples and references). The dithionite-citrate method determines the amount of free iron and aluminum $n$ oxides, hydrous oxides, and organic substances. Most of these forms of iron and aluminum do not occur in the parent material. Five forms of phosphorus (P) were measured; they include: calcium-bound $\mathrm{P}$ (Pca) in the original minerals, occluded $P$ (Poc) in coatings or concretions composed of oxides and hydrous oxides of iron and aluminum, non-occluded $\mathrm{P}$ (Pnoc) on the surfaces of the above oxides and hydrous oxides, organic-bound $\mathrm{P}(\mathrm{Po})$, and total $\mathrm{P}(\mathrm{Pt})$, which is the total of the above forms.

\section{TRENDS IN THE FIELD AND LABORATORY DATA FOR THE SOIL CHRONOSEQUENCE}

Systematic trends in field and laboratory data have been observed for most soil chronosequences (Birkeland, 1984a). On the basis of data for similar soils in areas of similar climate, we hypothesized that the soils in the study area would have the following trends with time. A horizons would (1) increase in thickness, (2) become darker (decrease in color value), and (3) differ in percentages of organic carbon (C) and nitrogen $(\mathrm{N})$. $\quad B$ horizons would (1) increase in thickness and clay content, (2) develop redder hues and higher chromas, and (3) possibly have clay films and silt caps (coatings composed of silt and clay) on clasts (Burns, 1980; Birkeland, 1984a, appendix 1). Cox horizons would (1) increase in thickness and (2) develop redder hues and higher chromas. The $\mathrm{pH}$ values of $\mathrm{A}$ and $B$ horizons should show an overall decrease with time, cation exchange capacity (CEC) should increase as the amounts of organic matter and clay content increase, and dithionite-extractable iron (Fed) and aluminum (Ald) should increase. Phosphorus trends are complex because they depend on the degree of leaching (Walkel and Syers, 1976). In general, with sufficient leaching, acid-extractable calcium-bound $\mathrm{P}$ should decrease; occluded, non-occluded, and organicbound P should increase; and total P should decrease.

The morphology and the physical, chemical, and mineralogical properties of the soils in Arapaho cirque exhibit numerous significant trends with time (supp. tables $1-4$, respectively).

\section{POST-GANNETT PEAK SOIL}

The post-Gannett Peak soil is an A/Cox profile that is only $3 \mathrm{~cm}$ thick. This soil has minimal development and lacks diagnostic horizons. It is classified as a Pergelic Cryorthent (Soil Survey Staff, 1975). The A horizon is $0.5 \mathrm{~cm}$ thick and patchy; the Cox horizon is thin and very weakly oxidized. The percentages of total sand, silt, and clay suggest a change in parent material between the Cox and $\mathrm{Cu}$ horizons, even though the percentages for the various sand-size fractions do not seem to support this interpretation. Chemical data indicate considerable pedogenesis in the $\mathrm{A}$ and Cox horizons relative to the $\mathrm{Cu}$ horizon ${ }^{4}$. Specifically, $\mathrm{pH}$ has decreased, exchange acidity has increased, and there are increases in $\mathrm{C}, \mathrm{N}$, Fed, Ald, and Po that are more likely to be pedogenic than due to variations in the parent material. The ranking of the exchangeable cations according to their relative abundances is $\mathrm{Ca} \gg \mathrm{K}>\mathrm{Na}$, and no $\mathrm{Mg}$. The ranking of the clay-mineral peaks according to their relative heights is kaolinite $\simeq$ mica $>$ chlorite $\simeq$ smectite $>$ vermiculite. Kaolinite and mica peaks are slightly higher in the A horizon than in the $\mathrm{Cu}$ horizon.

\section{POST-AUDUBON SOIL}

The post-Audubon soil is an A/AC/Cox profile that is different from the post-Gannett Peak soil in some morphological and chemical characteristics. The $\mathrm{A}$ and $\mathrm{AC}$ horizons have a combined thickness of 27 $\mathrm{cm}$. Although they are relatively dark, they do not meet the color requirements of the mollic or umbric epipedon. The Cox horizon is not red enough to qualify as a cambic horizon. This soil, therefore, is classified as a Pergelic Cryorthent even though it is better developed than the post-Gannett Peak soil. Sandfraction data suggest a change in the parent material at a depth of $27 \mathrm{~cm}$, but because the total amounts of sand, silt, and clay are fairly uniform with depth, and a change in parent material was not identified in the field, the parent material is considered to be uniform throughout the profile. Chemical trends are somewhat similar to those for the post-Gannett Peak soil; however, some of the chemical data for the postAudubon soil have higher values than those of the postGannett Peak soil or indicate a greater depth of chemical alteration. The ranking of the exchangeable cations according to their relative abundances are the same as for the post-Gannett Peak soil, but the amounts are higher. The ranking of the clay-mineral peaks according to their relative heights is fairly similar in each horizon, with smectite $\geq$ kaolinite $>$ mica $>$ chlorite $\geq$ vermiculite(?). Vermiculite(?) occurs in only the A horizon.

\footnotetext{
${ }^{4}$ The total chemical composition of the soils in Arapaho cirque are presented in supplementary tables 5 and 6 . Although these data are not discussed in the text, they are included in this report because they serve as a chemical data base for the soils, and they aid in the interpretation of the extractive chemical properties and clay mineralogy of the soils.
} 


\section{POST-TRIPLE LAKES SOIL}

The post-Triple Lakes soil has an $\mathrm{A} / \mathrm{Bw} / \mathrm{Cox}$ profile. It is different from the post-Audubon soil because it has a B horizon. The dark color of the A horizon, the content of organic carbon, and a base saturation value of 50 percent place it on the border between a mollic and umbric epipedon. The B horizon is a cambic ${ }^{5}$ (color) B with a 10YR hue and chromas of 3 and 4. This soil is either a Pergelic Cryumbrept or a Pergelic Cryoboroll. Parent material layering may account for the slight increase in silt and clay in the $A$ horizon, or some of these fines could be due to the addition of airborne dust. Some of the chemical properties, such as $\mathrm{pH}$ and Fed, are similar to those for the post-Audubon soil but the other properties are markedly different. For example, exchange acidity, C, $\mathrm{N}$, Ald, and Po are all much higher for the post-Triple Lakes soil than for the post-Audubon soil. The data for the other $P$ fractions are difficult to interpret, but if the values for the post-Gannett Peak soil are considered to be an approximation of parent material values, then the relatively low values for Pca, except for the $B$ horizon, suggest loss of $P$ owing to the weathering of apatite. The high value of $\mathrm{Pca}$ in the $\mathrm{B}$ horizon cannot be explained. This is the youngest soil to have $\mathrm{Mg}$ on the exchange complex, and it is present only in the A horizon where the relative abundance ranking of the exchangeable cations is $\mathrm{Ca} \gg \mathrm{K}>\mathrm{Mg}$ $>\mathrm{Na}$. Clay mineral peak heights suggest the following ranking: smectite $\geq$ kaolinite $>$ mica.

\section{POST-SATANTA PEAK SOILS}

The post-Satanta Peak soils are characterized by an $\mathrm{A} / \mathrm{BW}$ (or Bt)/Cox profile, and are the best developed soils of the chronosequence. Soils at sites $\mathrm{CO} 4$ and $\mathrm{CO} 6$ have mollic epipedons, those at $\mathrm{CO} 5$ and CO7 have umbric epipedons, and the soil at CO8 has an ochric epipedon. B horizons have $10 \mathrm{YR}$ and $7.5 \mathrm{YR}$ hues and chromas of 4 and 5 . Three of the five soils have $B t$ horizons that have a sufficient clay increase to qualify as argillic horizons (Soil Survey Staff, 1975). Typically, the argillic horizon is defined on the basis of the clay content of the B horizon compared to that of the A horizon. In these soils, however, the higher silt and clay content of the A horizon relative to that of the underlying till suggests the presence of some airborne dust in the A horizon. Much of this dust may remain in the $A$ horizon, although some of it may be translocated into the $B$ horizon, producing more of a textural contrast between the $B$ and $C$ horizons than

\footnotetext{
5 According to the Soil Survey Staff (1975), the B horizon meets the color requirement, but is too coarse grained to meet the textural requirement for a cambic horizon. We recommend waiving the textural requirement, because it is too arbitrary for pedologic studies; therefore, the B horizon is here considered to be a cambic horizon. For comparison, the parent material color is considered to be the same as that of the $\mathrm{Cu}$ horizon of the post-Gannett Peak soil (supp. table 1).
}

between the $\mathrm{A}$ and $\mathrm{B}$ horizons. In such cases, we use the clay content of the $B$ horizon versus that of the $C$ horizon to determine whether or not a B horizon is argillic ${ }^{6}$.

The post-Satanta Peak soils belong to several different taxonomic units. The soil at $\mathrm{CO} 8$ is a Pergelic Cryochrept, the soil at $\mathrm{CO} 7$ is a Pergelic Cryumbrept, and those with argillic horizons are either Argic Pergelic Cryoboroll (CO4) or Pergelic Cryoboralf (CO5 and CO6). The last term is not in Soil Taxonomy (Soil Survey Staff, 1975), but it is used here to refer to cold soils (mean annual temperatures less than $0^{\circ} \mathrm{C}$ ) with argillic horizons. Parent material layering is common in these soils; it is identified by the variation in gravel content with depth and by the difference in texture of the near-surface horizons. Except for $\mathrm{pH}$ and $\mathrm{Pt}$, most values for chemical properties are commonly as much as 2 times greater than those for the post-Triple Lakes soil. In contrast, Pca values are much less for the post-Satanta Peak soils than they are for the post-Triple Lakes soil, and may indicate more intense leaching and (or) prolonged leaching of the post-Satanta Peak soils. A large proportion of exchangeable $\mathrm{Mg}$ exists in these soils, especially in the $A$ horizons, where the ranking of exchangeable cations is $\mathrm{Ca}>\mathrm{Mg}>\mathrm{K}>\mathrm{Na}$. The general trend of the clay mineral peak heights for the five soils is kaolinite $\simeq$ smectite $>$ mica $\geq$ chlorite $\geq$ interstratified mica-chlorite. Depth trends are difficult to interpret, but smectite is low at depth and increases in either the $A$ or B horizon, mica increases toward the surface, and kaolinite decreases toward the surface. These trends could be due primarily to chemical weathering and (or) the addition of airborne dust to the near-surface horizons.

\section{SUMMARY OF SOIL-PROFILE CHARACTERISTICS}

Several trends with time are readily apparent. One is the genetic sequence of soil taxonomic units: Pergelic Cryorthent (as much as about 2,000 yr) to Pergelic Cryumbrept (about 4,000 yr) to Pergelic Cryoboralf (about 10,000-12,000 yr). Color B horizons with a $10 \mathrm{YR}$ hue, that we designate as cambic horizons, form in about 2,000 to 4,000 years. Bt horizons with a $10 \mathrm{YR}$ or a $7.5 \mathrm{YR}$ hue, that we designate as argillic horizons, form in about 5,000 to 12,000 years. Most chemical properties show progressive change with time. By about 1,000 to 2,000 years, $\mathrm{pH}$ has reached minimum values common to all of the older soils. In contrast, all other chemical properties continue to change over the duration of the chronosequence. It is not known if the oldest soils are in a steady-state condition because data for older soils would be needed to make this judgment. In general,

${ }^{6}$ The Bt horizons of the post-Satanta Peak soils are considered to be argillic horizons, on the basis of clay content, even though they lacked clay films when examined in the field. Soil thin sections are needed in order to definitely determine the presence or absence of translocated clay, which is diagnostic of argillic horizons. 
CEC increases with time. It tends to increase with both organic matter and clay content, although it is also dependent in part on the type of clay minerals present. The exchangeable cations display the following trends: $\mathrm{Na}$ and $\mathrm{K}$ are present in low amounts and show slight increases with time; $\mathrm{Ca}$ is the dominant cation for soils of all ages, and it increases with time; and $\mathrm{Mg}$ occurs first in the post-Triple Lakes soil where it is restricted to the $\mathbf{A}$ horizon, and is second to $\mathrm{Ca}$ in abundance. These trends could be due to soil-forming processes and (or) the addition of airborne dust with exchangeable cations dominated by $\mathrm{Ca}$ and $\mathrm{Mg}$. The amounts of $\mathrm{C}$ and $\mathrm{N}$ in the $\mathrm{A}$ horizons increase systematically with time; the $C / N$ ratio of the A horizons, however, shows little change with time.

Eolian materials are important to some of the properties of some of the soils in Arapaho cirque. Material collected from melting snow and ice at the end of the ablation season is considered to be representative of the local eolian materials. One sample from Arapaho Glacier has a sand/silt/clay percentage ratio of $38 / 42 / 20$ (Burns, 1980). Other data also show that the eolian materials of the region are fine grained (Thorn and Darmody, 1980, 1985; Burns, 1980). In alpine areas, eolian material could theoretically either (1) form a discrete surface layer, (2) be physically mixed with till or other coarsegrained deposits, or (3) some of it, mainly the silt and clay fractions, be translocated to depth in the soil. Translocation of eolian material may have produced some of the silt caps on clasts in the post-Audubon and older soils, and may account for much of the clay accumulation in the $\mathrm{Bt}$ horizons of some of the postSatanta Peak soils?

Trends in clay mineralogy are difficult to interpret because the primary clay minerals can come from different sources: the glacial and periglacial parent materials or eolian materials. Once deposited, the clays may alter to more stable minerals, and some or most of them may be translocated downward in the profile. The clay mineralogy of the $\mathrm{Cu}$ horizon of the post-Gannett Peak soil is characterized by kaolinite $\sim$ mica $>$ smectite $>$ vermiculite and should approximate that of the parent material at depth in all of the profiles. The clay mineralogy of the material collected on Arapaho Glacier is characterized by mica $>$ chlorite $>$ kaolinite $\sim$ smectite and 1-1:4 nm mixedlayer clay (Burns, 1980), and may be similar to that of eolian material added to the soils of this study. Trends in clay mineralogy over the past 12,000 years seem to be the depletion and (or) dilution of kaolinite, smectite, and mica, and the formation and (or) addition of 1-1.4 $\mathrm{nm}$ mixed-layer clay minerals. We cannot discriminate between trends due chiefly to pedogenic processes and those due chiefly to eolian processes.

$7^{7}$ Not all silt caps are pedologic features, because some of them occur in deposits unaffected by pedogenesis (P.W. Birkeland, unpub. data, 1984). These non-pedogenic silt caps are considered to be a parent material property.

\section{COMPARISON WITH PREVIOUS WORK}

The data presented in this report compare well with those for other soil chronosequence studies in the Colorado Front Range and the rest of the Rocky Mountain region.

Benedict (1973) did the initial fieldwork on the soils in Arapaho cirque. The soil morphological trends he described are very similar to those in this report. He did not describe a soil on the Triple Lakes rockglacier deposit (soil CO3), and he indicated that there was considerable overlap in the properties of the soils formed from the type Triple Lakes till (the postSatanta Peak soils of this study) and the type Satanta Peak till. Data for the soil formed in the type Satanta Peak till at Caribou Lake (fig. 1) are presented in Birkeland and Shroba (1974) and Benedict (1985). The overlap in morphological properties of the above soils can be attributed to soil-forming factors other than time, or the type Triple Lakes till (the Satanta Peak till deposits of this study) and the type Satanta Peak till could be the same age. Mahaney (1974) did the first detailed work on the soils in this area of the Colorado Front Range that included laboratory analyses. In general, we agree with most of Mahaney's morphological and analytical data.

Mahaney's work differs from ours in that he (1) described a much thicker Cox horizon for the postGannett Peak soil than we did, (2) reported only $10 \mathrm{YR}-$ hue colors for both the post-Gannett Peak and postAudubon soils, and (3) identified an iron-enriched Bs horizon (his Bir horizon) in one of his post-Triple Lakes soils. In addition, he used 4 micrometers as the upper size limit for the total clay fraction, whereas 2 micrometers is the accepted size limit between silt and clay.

Our main differences with the work of Dixon (1983) are that he recognized a B horizon in the postAudubon soil, and the clay percentages that he obtained for most of his soils are higher than ours.

Albino (1984) reported trends in soil development with time that are similar to those of this study, although she recognized $B$ horizons in her post-Gannett Peak soil and in one of her post-Audubon soils, and she reported Fed values that are higher than those we report for our soils.

Shroba (1977; Shroba and Birkeland, 1983) studied alpine soils equivalent in age to those in Arapaho cirque over a large region of the Rocky Mountains and reported findings that are similar to ours. Broad similarities are also seen between alpine soils in Arapaho cirque and soils of similar ages in the Wind River Mountains, Wyoming (Miller and Birkeland, 1974). We believe that the similarity of soil properties reported by different workers throughout the Rocky Mountains lends credence to the use of soils as a criterion for broad, regional correlations of Quaternary deposits.

Trends in the relative abundance of clay minerals with time reported in other studies of Holocene soils in the region differ somewhat from those of this study. Mahaney (1974) reported that illite decreased and chlorite, montmorillonite, and mixed-layer illitemontmorillonite increased with time in soils in Arapaho cirque. Dixon's $(1983,1986)$ work in Arapaho cirque indicated depletion of kaolinite and the 
alteration of biotite to hydrobiotite, vermiculite, and smectite. In a cirque $6 \mathrm{~km}$ south of Arapaho cirque, Albino (1984) recognized the depletion of mica, chlorite, and randomly interstratified mica/smectite, and the formation of ordered mica/smectite and intergrade chlorite. In the Colorado Rocky Mountains, Shroba (1977; Shroba and Birkeland, 1983) described a decrease in mica and an increase in mixed-layer clays $(1-1.8 \mathrm{~nm})$ with time in alpine areas that may have never been forested.

\section{TRENDS IN SOIL DEVELOPMENT INDICES WITH TIME}

\section{Definitions}

Soil field descriptions are quite complicated and involve many qualitative observations and some quantitative measurements. Several indices have been devised to integrate the descriptive data for either a horizon or an entire profile into a single numerical value that serves as a ranking of the degree of development of the horizon or profile. Two of the better known indices have been developed by Bilzi and Ciolkosz (1977) and Harden (1982a; Harden and Taylor, 1983). Both indices are somewhat similar in that the properties of each horizon are compared to those of either the $C$ horizon (Bilzi and Ciolkosz, 1977) or the parent material (Harden, 1982a). A numerical value is assigned based on the difference between two horizons or a horizon and the parent material. For both methods, a total value can be calculated for each horizon; the larger the value, the more the horizon differs in most pedological properties from either the $\mathrm{C}$ horizon or the parent material. One problem with each of these methods is that soils commonly develop to different depths. The difference in depths alone can have a major influence on index values, because horizon index values are multiplied by horizon thickness.

For this study we have modified each of the methods so that they will yield a value more closely related to profile development to a uniform depth (see discussion in Birkeland, 1984a, and in Harden and Taylor, 1983). In order to take into account the fact that soils commonly are described to different depths, we increased the thickness of the lowest horizon so that each profile had the same thickness as the thickest soil of the chronosequence, which in this study was $85 \mathrm{~cm}$. Although this approach created some problems (Birkeland, 1984a), it permitted comparison of the soils to a common depth. Higher index values in these systems usually correspond to greater soil development.

The systematic reddening of soil color with time in well-drained soils has also been the basis for other development indices. The Munsell color notations can be converted to a single index value; three such indices are used here to assess soil development. The first is the Buntley-Westin (B-W) color index (Buntley and Westin, 1965), in which hue is assigned a numerical value $(7.5 \mathrm{YR}=4, \quad 10 \mathrm{YR}=3,2.5 \mathrm{Y}=2,5 \mathrm{Y}=1)$ that is multiplied by the chroma. The second is the Hurst $(\mathrm{H})$ color index (Hurst, 1977), in which hue is assigned a numerical value ( $5 \mathrm{YR}=15,7.5 \mathrm{YR}=17.5,10 \mathrm{YR}=20$, etc.) that is multiplied by the fraction formed by the value and chroma (value/chroma). The third is rubification, one of several properties of the soil development index of Harden (1982a), in which the color of each horizon is compared with that of the parent material. In this system, each shift toward a redder hue and each shift toward higher chromas is assigned a value of 10 points. For all three color indices, we multiplied the numerical value for each horizon by horizon thickness, once the thickness of the lowest horizon was adjusted so that the thickness of all profiles was the same (85 $\mathrm{cm})$. We then summed the horizon values to yield a total value for the soil profile. Both the B-W color index and rubification increased with the redder hues and higher chromas that accompany greater degree of pedogenesis, whereas the $\mathrm{H}$ color index decreased.

One problem common to all of these color indices is that the effect of eolian parent materials is not known. In this report, we considered the colors of the eolian parent materials to be similar to those of the glacial parent materials, although these colors may not be representative of all of the soil parent materials. This is especially true if some of the eolian parent materials were derived from previously weathered deposits.

\section{Results}

The point values for each of the index systems change in a systematic manner with time (table 4). Both of the profile-development indices increase with time (fig. 3). Values for both indices define linear functions and have similar correlation coefficients (table 5). All color indices change with time (fig. 4). Both rubification and $B-W$ values define linear functions. Rubification has a higher correlation coefficient than the $\mathrm{B}-\mathrm{W}$ index. In contrast, values for the $\mathrm{H}$ index define a power function with a high, negative correlation coefficient. Comparison of the standard deviations of the various indices for the postSatanta Peak soils, expressed as a percentage of the mean (table 6), indicates that the profile indices have less variation than the color indices, and that the rubification and $\mathrm{H}$ indices have less variation than the $\mathrm{B}-\mathrm{W}$ index.

We calculated the above indices to assess their usefulness for the correlation of surficial deposits in alpine environments. The results presented in this report are encouraging, as are those for the Wind River Mountains, Wyoming (fig. 1-10 in Birkeland, $1984 a$ ) and those for part of the Southern Alps, New Zealand (Birkeland, 1984b). More work on soil indices in different areas is needed in order to further test their use fulness.

\section{CONCLUSIONS}

One of the goals of soil chronosequence studies is to evaluate the usefulness of various soil properties for estimating the ages of surficial deposits. The discussion in this report pertains to cirque deposits above treeline in the Colorado Front Range. Detailed field descriptions are essential in soil chronosequence 
studies because field-description data can be used to calculate index values that may be useful age indicators.

For greater accuracy, color data collected in the field should be compared with data for the air-dried seived samples, because the latter give the most consistent results. Laboratory data vary in their usefulness in soil chronosequence studies. In this study, the most useful laboratory data for differentiating deposits of different ages were particle size, Fed, Ald, Pca, C, and N.

Table 4. Values for soil-profile and color indices of the soils

[All values are for 85 -cm-thick soil profiles. Soil-profile sites are shown on figure 2 . Buntley-Westin and Hurst color indices refer to dry colors. nd, not determined]

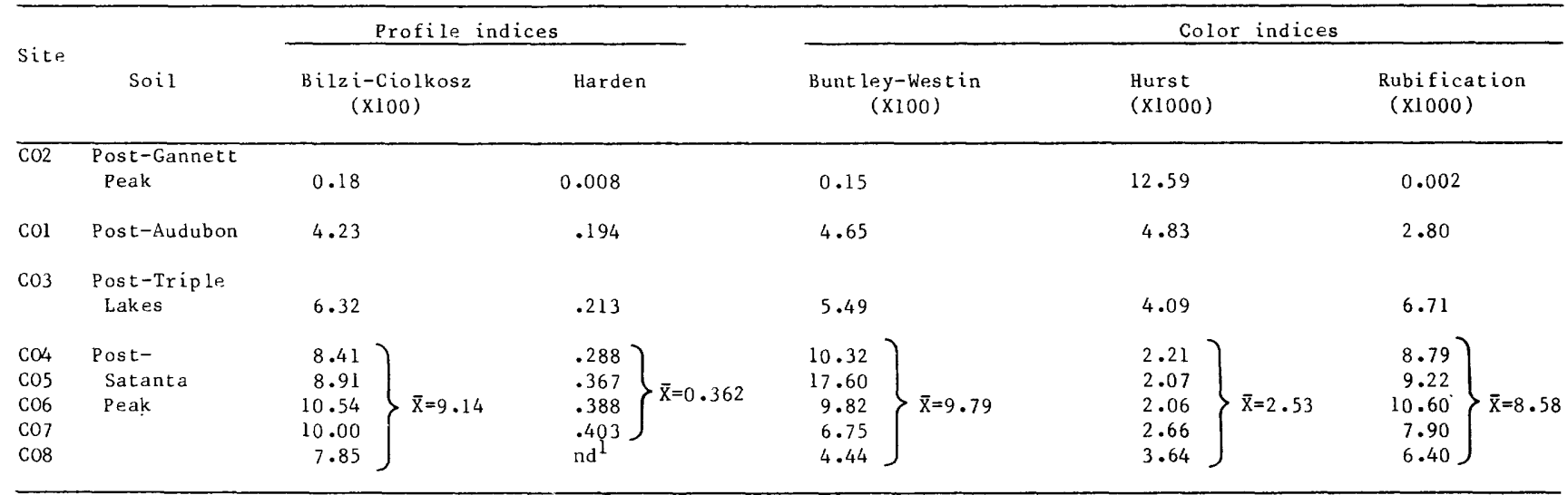

${ }^{1}$ No pH data. Because $\mathrm{pH}$ is important to the calculation of Harden's profile index, the profile index was not determined for this soil.

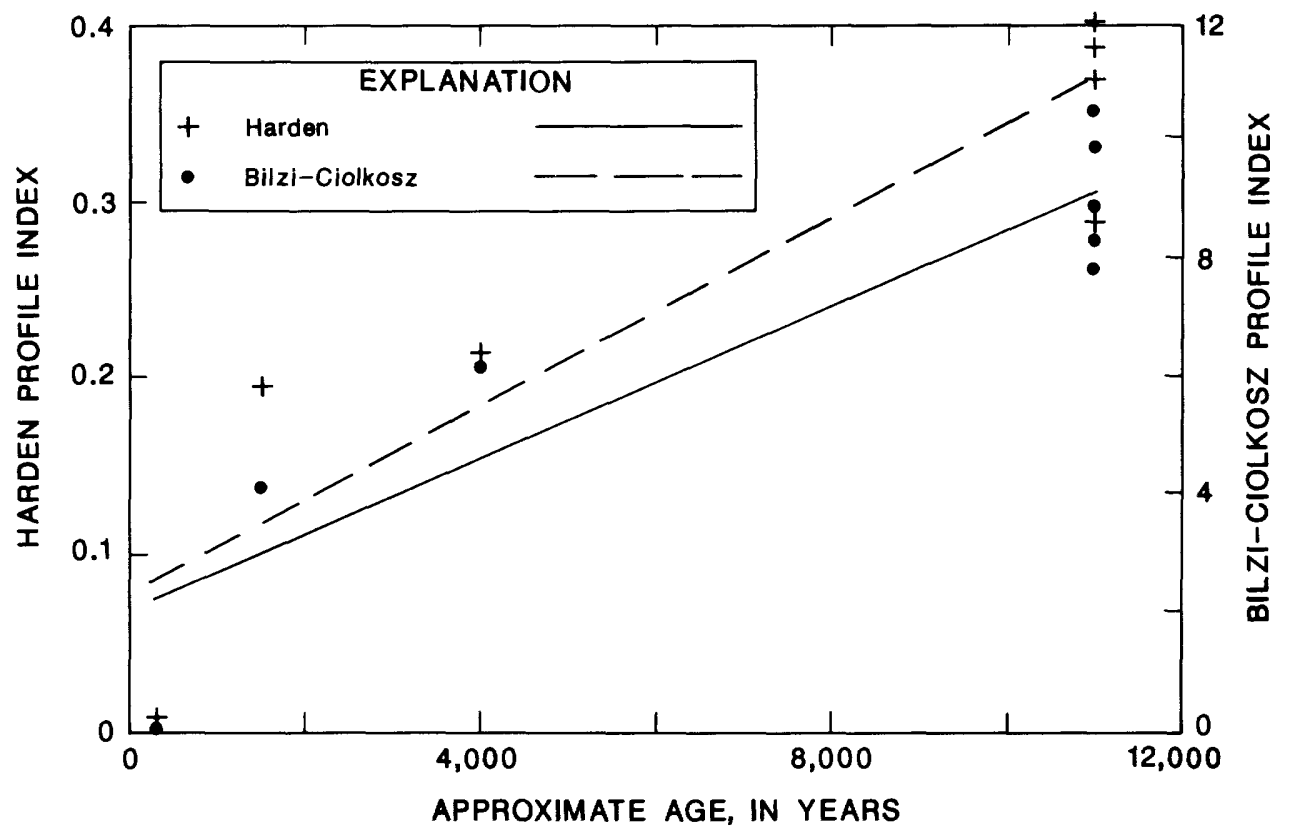

Figure 3. Plot of profile-development indices versus approximate age of soil parent materials. Trend lines based on regression equations in table 5; data from supplementary table 1. Ages of soil parent materials used to plot data are as follows: $300 \mathrm{yr}$ for Gannett Peak deposits; $1,500 \mathrm{yr}$ for Audubon deposits; 4,000 yr for the Triple Lakes deposit; and 11,000 yr for Satanta Peak deposits. 


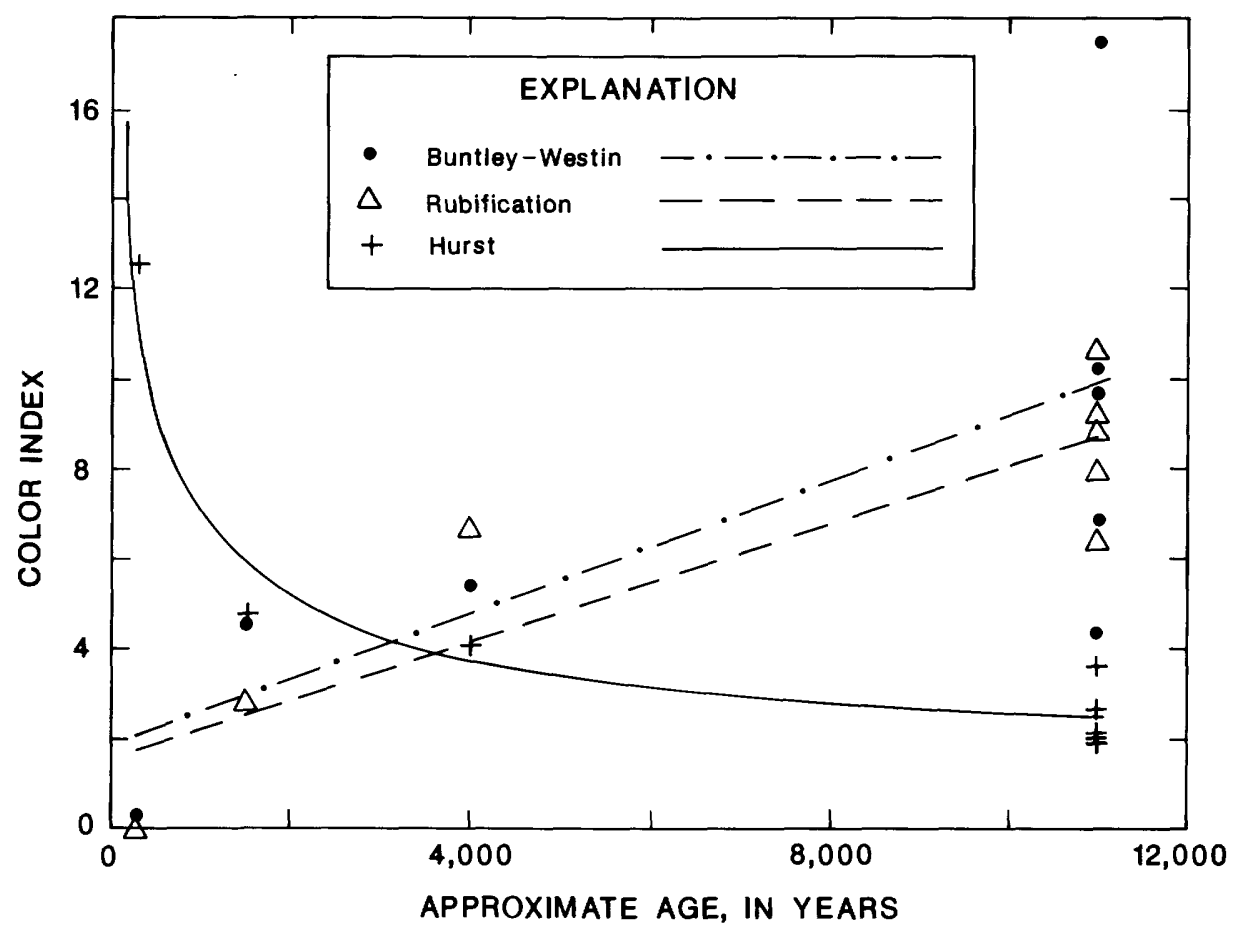

Figure 4. Plot of color indices versus approximate age of soil parent materials. Trend lines based on regression equations in table 5; data from supplementary table 1. For ages of soil parent materials, see figure 3 .

Table 5. Regression-equation data for the soil-profile and color indices

[Regression models used: 1 , linear; $\mathrm{p}$, power. $\mathrm{X}$, age of soil parent material in years]

\begin{tabular}{lcccc}
\hline $\begin{array}{l}\text { Property } \\
(\mathrm{Y})\end{array}$ & Model & Regression equation & $\begin{array}{c}\text { Correlation } \\
\text { coefficient }\end{array}$ & $\begin{array}{c}\text { Significance } \\
\text { level }\end{array}$ \\
\hline $\begin{array}{l}\text { Harden index } \\
\begin{array}{l}\text { Bilzi-Ciolkosz } \\
\text { index }\end{array}\end{array}$ & 1 & $\mathrm{Y}=0.08+0.000026 \mathrm{X}$ & 0.91 & 0.01 \\
$\begin{array}{l}\text { Buntley-Westin } \\
\text { index }\end{array}$ & 1 & $\mathrm{Y}=1.88+0.00073 \mathrm{X}$ & .67 & .01 \\
$\begin{array}{l}\text { Hurst index } \\
\text { rubification }\end{array}$ & $\mathrm{P}$ & $\log \mathrm{Y}=2.14-0.432 \log \mathrm{X}-.95$ & .00 \\
\end{tabular}

Table 6. Selected statistical measures for the soil-profile and color indices for the post-Satanta Peak soils

[Individual index values are listed in table 4]

\begin{tabular}{|c|c|c|c|c|c|}
\hline \multirow{2}{*}{$\begin{array}{l}\text { Statistical } \\
\text { measure }\end{array}$} & \multicolumn{2}{|c|}{ Profile indices } & \multicolumn{3}{|c|}{ Color indices } \\
\hline & $\begin{array}{l}\text { i-Ciolkosz } \\
(\mathrm{X} 100)\end{array}$ & Harden & $\begin{array}{c}\text { Bunt ley-West in } \\
(\mathrm{x} 100)\end{array}$ & $\begin{array}{l}\text { Hurst } \\
(\mathrm{X} 1000)\end{array}$ & $\begin{array}{c}\text { Rubification } \\
(\mathrm{X} 1000)\end{array}$ \\
\hline Mean & 9.14 & 0.362 & 9.79 & 2.53 & 8.58 \\
\hline Standard deviation & 1.11 & .051 & 4.98 & .67 & 1.56 \\
\hline $\begin{array}{l}\text { Standard deviation } \\
\text { as a percentage } \\
\text { of the mean }\end{array}$ & .12 & .141 & .51 & .26 & .18 \\
\hline
\end{tabular}




\section{REFERENCES CITED}

Albino, K.C., 1984, Relative dating and soils of late Quaternary deposits, Devil's Thumb Lake Valley, Colorado Front Range: Boulder, University of Colorado, M.S. thesis, 165 p.

Barry, R.G., 1973, A climatological transect along the east slope of the Front Range, Colorado: Arctic and Alpine Research, v. 5, p. 89-110.

Benedict, J.B., 1967, Recent glacial history of an alpine area in the Colorado Front Range, U.S.A.-I. Establishing a lichen-growth curve: Journal of Glaciology, v. 6, p. 817-832.

1968, Recent glacial history of an alpine area in the Colorado Front Range, U.S.A.--II. Dating the glacial deposits: Journal of Glaciology, v. 7, p. 77-87.

1973, Chronology of cirque glaciation, Colorado Front Range: Quaternary Research, v. 3, p. 584599.

1981, The Fourth of July Valley: Ward, Colo., Center for Mountain Archeology, Research Report No. 2, 139 p.

1985, Arapaho Pass-glacial geology and archeology at the crest of the Colorado Front Range: Ward, Colo., Center for Mountain Archeology, Research Report No. 3, 197 p.

Benedict, J.B., and Benedict, A.D., 1984, Guidebook to the glacial geology, archeology, and natural history of the Arapaho Pass area, Colorado Front Range: Ward, Colo., Center for Mountain Archeology, American Quaternary Association (AMQUA) guidebook, $46 \mathrm{p}$.

Bilzi, A.F., and Ciolkosz, E.J., 1977, A field morphology rating scale for evaluating pedological development: Soil Science, v. 124, p. 45-48.

Birkeland, P.W., 1984a, Soils and geomorphology: New York, Oxford University Press, 372 p.

$1984 \mathrm{~b}$, Holocene soil chronofunctions, Southern Alps, New Zealand: Geoderma, v. 34, p. 115-134.

Birkeland, P.W., and Shroba, R.R., 1974, The status of the concept of Quaternary soil-forming intervals in the western United States, in Mahaney, W.C., ed., Quaternary environments: Toronto, Atkinson College/York University Geography Monograph No. 5, p. 241-276.

Buntley, G.J., and Westin, F.C., 1965, A comparative study of developmental color in a ChestnutChernozem-Brunizem soil climosequence: Soil Science Society of America Proceedings, v. 29, p. 579-582.

Burke, R.M., and Birkeland, P.W., 1979, Reevaluation of multiparameter relative dating techniques and their application to the glacial sequence along the eastern escarpment of the Sierra Nevada, California: Quaternary Research, v. 11, p. 21-51. 1983, Holocene glaciation in the mountain ranges of the western United States, in Wright, H.E., Jr., ed., Late-Quaternary environments of the United States, v. 2, The Holocene: Minneapolis, University of Minnesota Press, p. 3-11.

Burns, S.F., 1980, Alpine soil distribution and development, Indian Peaks, Colorado Front Range: Boulder, University of Colorado, Ph.D. thesis, $360 \mathrm{p}$.

Burns, S.F., and Tonkin, P.T., 1982, Soil-geomorphic models and the spatial distribution and development of alpine soils, in Thorn, C.E., ed., Space and time in geomorphology: London, George Allen and Unwin, p. 25-43.

Busacca, A.J., 1982, Geologic history and soil development, northeastern Sacramento Valley, California: Davis, University of California, Ph.D. thesis, $348 \mathrm{p}$.

Busacca, A.J., Aniku, J.R., and Singer, M.J., 1984, Dispersion of soils by an ultrasonic method that eliminates probe contact: Soil Science Society of America Journal, v. 48, no. 5, p. 1125-1129.

Davis, P.T., 1982, Chronology of Holocene glaciation, Arapaho Cirque, Colorado Front Range: Abstracts for the XI Congress of the International Union for Quaternary Research, v. II, Moscow, p. 54 .

-_-1987, Late Pleistocene age for type Triple Lakes moraines, Arapaho cirque, Colorado Front Range abs. : Geological Society of America Abstracts with Programs, v. 19, no. 5, p. 270.

Davis, P.T., Burns, S.F., and Caine, Nel, 1984, Guidebook to Holocene deposits in Arapaho cirque, Colorado Front Range: American Quaternary Association 8th biennial meeting, Boulder, Colorado, 28 p.

Davis, P.T., Upson, Susan, and Waterman, S.E., 1979, Lacustrine sedimentation variation as an indicator of late Holocene climatic fluctuation, Arapaho cirque, Colorado Front Range abs.: Geological Society of America Abstracts with Programs, v. 11 , no. 7, p. 410 .

Davis, P.T., and Waterman, S.E., 1979, New radiocarbon ages for type Triple Lakes moraines, Arapaho cirque, Colorado Front Range abs. : Geological Society of America Abstracts with Programs, v. 11 , no. 6, p. 270.

Deming, W.E., 1943, Statistical adjustment of data: New York, Wiley, 261 p.

Dethier, D.T., and Bethel, John, 1981, Surficial deposits along the Cowlitz River near Toledo, Lewis County, Washington: U.S. Geological Survey Open-File Report 81-1043, 10 p.

Dixon, J.E., 1983, Chemical weathering of late Quaternary cirque deposits in the Colorado Front Range: Boulder, University of Colorado, Ph.D. thesis, $174 \mathrm{p}$.

1986, Solute movement on hillslopes in the alpine environment of the Colorado Front Range, in Abrahams, A.D., ed., Hillslope processes: London, George Allen and Unwin, p. 139-159.

Gable, D.J., 1980, The Boulder Creek Batholith, Front Range, Colorado: U.S. Geological Survey Professional Paper 1101, 88 p.

Guthrie, R.L., and Witty, J.E., 1982, New designations for soil horizons and layers and the new Soil Survey Manual: Soil Science Society of America Journal, v. 46, p. 443-444.

Harden, J.W., 1982a, A quantitative index of soil development from field descriptions: Examples from a chronosequence in central California: Geoderma, v. 28 , no. 1 , p. 1-28.

$1982 \mathrm{~b}$, A study of soil development using the geochronology of Merced River deposits: Berkeley, University of California, Ph.D. thesis, $237 \mathrm{p}$. 
Harden, J.W., and Marchand, D.E., 1977, The soil chronosequence of the Merced River area, California, in Singer, M.J., ed., Soil development, geomorphology, and Cenozoic history of the northeastern San Joaquin Valley and adjacent areas, California, chap. 6 of American Society of Agronomy-Soil Science Society of AmericaGeological Society of America, joint field session, 1977, guidebook: Davis, Calif., American Society of Agronomy.

1980, Quaternary stratigraphy and interpretation of soil data from the Auburn, Oroville, and Sonora areas along the Foothills fault system, western Sierra Nevada, California: U.S. Geological Survey Open-File Report 80-30, 57 p.

Harden, J.W., and Taylor, E.M., 1983, A quantitative comparison of soil development in four climatic regimes: Quaternary Research, v. 20, p. 342-359.

Hurst, V.J., 1977, Visual estimation of iron in saprolite: Geological Society of America Bulletin, v. 88 , p. $174-176$.

Jenny, H., 1980, The soil resource: New York, Springer-Verlag, $377 \mathrm{p}$.

Johnson, J.B., 1979, Mass balance and aspects of the glacier environment, Front Range, Colorado, 1969-1973: Boulder, University of Colorado, Ph.D. thesis, 287 p.

Komarkova, V., and Webber, P.J., 1978, An alpine vegetation map of Niwot Ridge, Colorado: Arctic and Alpine Research, v. 10, p. 1-29.

Litaor, M.I., 1987, The influence of eolian dust on the genesis of alpine soils in the Front Range, Colorado: Soil Science Society of America Journal, v. 51 , no. 1 , p. 142-147.

Machette, M.N., 1983, Geologic map of the southwest quarter of the Beaver quadrangle, Beaver County, Utah: U.S. Geological Survey Miscellaneous Investigations Series Map I-1444, scale 1:24,000.

Machette, M.N., and Steven, T.A., 1983, Geologic map of the northwest quarter of the Beaver quadrangle, Beaver County, Utah: U.S. Geological Survey Miscellanaeous Investigations Series Map I1445, scale 1:24,000.

Machette, M.N., Steven, T.A., Cunningham, C.G., and Anderson, J.J., 1984, Geologic map of the Beaver quadrangle, Beaver and Piute Counties, Utah: U.S. Geological Survey Miscellaneous Investigations Series Map I-1520, scale 1:50,000.

Madole, R.F., 1972, Neoglacial facies in the Colorado Front Range: Arctic and Alpine Research, v. 4, p. 119-130.

Mahaney, W.C., 1974, Soil stratigraphy and genesis of neoglacial deposits in the Arapaho and Henderson cirques, central Colorado Front Range, in Mahaney, W.C., ed., Quaternary environments: Toronto, Atkinson College/York University Geography Monograph No. 5, p. 197-240.

Marchand, D.E., and Allwardt, Alan, 1981, Late Cenozoic stratigraphic units, northwestern San Joaquin Valley, California: U.S. Geological Survey Bulletin $1470,70 \mathrm{p}$.

Marr, J.W., 1961, Ecosystems of the east slope of the Front Range in Colorado: Boulder, University of Colorado Studies, Series in Biology, No. 8, 134 p.

Marr, J.W., Johnson, A.W., Osburn, W.S., and Knorr, O.A., 1968, Data on mountain environments II. Front Range, Colorado, Four climax regions,

E14 Soil Chronosequences in the Western United States
1953-1958: Boulder, University of Colorado Studies, Series in Biology, No. 28, 171 p.

Meierding, T.C., and Birkeland, P.W., 1980, Quaternary glaciation of Colorado, in Kent, H.C., and Porter, K.W., eds., Colorado geology: Denver, Rocky Mountain Association of Geologists, p. 165-173.

Meixner, R.E., and Singer, M.J., 1981, Use of field morphology rating system to evaluate soil formation and discontinuities: Soil Science, v. 131 , no. 2 , p. 114-123.

Miller, C.D., and Birkeland, P.W., 1974, Probable preneoglacial age of the type Temple Lake moraine, Wyoming: Discussion and additional relative-age data: Arctic and Alpine Research, v. 6, p. 301306.

North American Commission on Stratigraphic Nomenclature, 1983, North American stratigraphic code: American Association of Petroleum Geologists Bulletin, v. 67 , no. 5, p. 841 875.

Pearson, R.C., 1980, Mineral resources of the Indian Peaks study area, Boulder and Grand Counties, Colorado: U.S. Geological Survey Bulletin 1463, $109 \mathrm{p}$.

Reheis, M.J., 1975, Source, transportation and deposition of debris on Arapaho Glacier, Front Range, Colorado: Journal of Glaciology, v. 14, p. $407-420$.

1984, Chronologic and climatic control on soil development, northeastern Bighorn Basin, Wyoming and Montana: Boulder, University of Colorado, Ph.D. thesis, 293 p.

Richmond, G.M., 1965, Glaciation of the Rocky Mountains, in Wright, H.E., Jr., and Frey, D.G., eds., The Quaternary of the United States: Princeton, N.J., Princeton University Press, p. 217-230.

Shroba, R.R., 1977, Soil development in Quaternary tills, rock-glacier deposits, and taluses, Southern and Central Rocky Mountains: Boulder, University of Colorado, $\mathrm{Ph} . \mathrm{D}$. thesis, $424 \mathrm{p}$.

Shroba, R.R., and Birkeland, P.W., 1983, Trends in late-Quaternary soil development in the Rocky Mountains and Sierra Nevada of the western United States, in Porter, S.C., ed., LateQuaternary environments of the United States, v. 1, The Late Pleistocene: Minneapolis, University of Minnesota Press, p. 145-156.

Soil Survey Staff, 1951, Soil survey manual: U.S. Department of Agriculture Handbook No. 18, $503 \mathrm{p}$.

1975, Soil taxonomy: U.S. Department of Agriculture Handbook No. 436, 754 p.

Thorn, C.E., and Darmody, R.G., 1980, Contemporary eolian sediments in the alpine zone, Colorado Front Range: Physical Geography, v. 1, p. 162171.

1985, Grain-size distribution of the insoluble component of contemporary eolian deposits in the alpine zone, Front Range Colorado: Arctic and Alpine Research, v. 17, p. 433-442.

Walker, T.W., and Syers, J.K., 1976, The fate of phosphorus during pedogenesis: Geoderma, v. 15, p. 1-19.

White, S.E., 1971, Rock glacier studies in the Colorado Front Range, 1961 to 1968: Arctic and Alpine Research, v. 3, p. 43-64. 
SUPPLEMENTARY TABLES 


\section{Supplementary table 1. ' Field descriptions}

[nd, not determi ned; no, not observed. Analysts: P. Birkeland, R. Burke, and J. Harden]

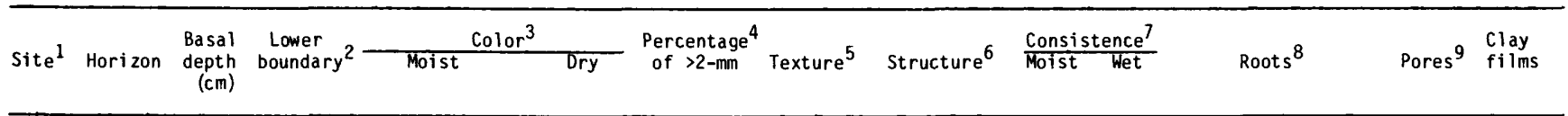

Gannet Peak till deposits, 0.1-0.35 ka

\begin{tabular}{|c|c|c|c|c|c|c|c|c|c|c|c|c|c|}
\hline $\mathrm{CO} 2$ & $\begin{array}{l}\mathrm{A} \\
\mathrm{Cox} \\
\mathrm{Cu}\end{array}$ & $\begin{array}{c}0.5 \\
3 \\
18+\end{array}$ & $\begin{array}{l}a, s \\
c, w \\
\text { no }\end{array}$ & $\begin{array}{l}10 Y R 3 / 2 \\
\text { nd } \\
7.5 Y 4 / 1\end{array}$ & $\begin{array}{l}10 Y R 4 / 2 \\
2.5 Y 6 / 2 \\
7.5 Y 5.5 / 1\end{array}$ & $\begin{array}{l}75 \\
75 \\
75\end{array}$ & $\begin{array}{l}S L \\
S L \\
S L\end{array}$ & $\begin{array}{l}\text { sg } \\
\text { sg } \\
\text { sg }\end{array}$ & $\begin{array}{l}10 \\
10 \\
10\end{array}$ & $\begin{array}{l}\text { ss, po } \\
\text { ss,po } \\
\text { ss,po }\end{array}$ & $\begin{array}{l}1 \text { medt } f i \\
\quad 1 \mathrm{fi} \\
\text { no }\end{array}$ & $\begin{array}{l}\text { no } \\
\text { no } \\
\text { no }\end{array}$ & $\begin{array}{l}\text { no } \\
\text { no } \\
\text { no }\end{array}$ \\
\hline
\end{tabular}

Audubon rock-glacier deposits, 0.95-2.4 ka

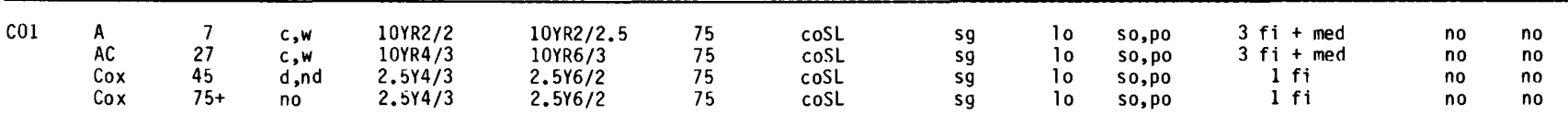

Triple Lakes rock-glacier deposit, 3-5.2 ka

\begin{tabular}{|c|c|c|c|c|c|c|c|c|c|c|c|c|c|}
\hline $\mathrm{CO}$ & $\begin{array}{l}A \\
2 A \\
2 B w \\
2 C o x\end{array}$ & $\begin{array}{l}12 \\
24 \\
49 \\
58+\end{array}$ & $\begin{array}{l}c, w \\
c, w \\
c, w \\
\text { no }\end{array}$ & $\begin{array}{l}10 Y R 2 / 2 \\
10 Y R 2 / 3 \\
10 Y R 4 / 4 \\
2.5 Y 4 / 1\end{array}$ & $\begin{array}{l}\text { 10YR3.5/2 } \\
10 Y R 4 / 3 \\
10 Y R 5.5 / 3 \\
2.5 Y 6 / 2\end{array}$ & $\begin{array}{l}\text { nd } \\
75 \\
75 \\
75\end{array}$ & $\begin{array}{l}\operatorname{coS} L \\
\cos L \\
\cos \\
\cos L\end{array}$ & $\begin{array}{c}2 \text { med sbk } \\
1 \text { med sbk } \\
\text { sg } \\
\text { sg }\end{array}$ & $\begin{array}{l}10 \\
f r \\
10 \\
10\end{array}$ & $\begin{array}{l}\text { so,po } \\
\text { so,po } \\
\text { so,po } \\
\text { so,po }\end{array}$ & $\begin{array}{c}3 \text { med, } 2 \mathrm{fi} \\
3 \text { med, } 2 \mathrm{fi} \\
\text { no } \\
\text { no }\end{array}$ & $\begin{array}{l}1 \text { med tub } \\
1 \text { med tub } \\
\text { no } \\
\text { no }\end{array}$ & $\begin{array}{l}\text { no } \\
\text { no } \\
\text { no } \\
\text { no }\end{array}$ \\
\hline
\end{tabular}

Satanta Peak till deposits, inner moraine, 10-12 ka

\begin{tabular}{|c|c|c|c|c|c|c|c|c|c|c|c|c|c|}
\hline $\mathrm{CO} 4$ & $\begin{array}{l}\mathrm{A} \\
2 \mathrm{Bt} \\
2 \mathrm{BC}\end{array}$ & $\begin{array}{l}14 \\
38 \\
62+\end{array}$ & $\begin{array}{l}\mathrm{c}, \mathrm{w} \\
\mathrm{g}, \mathrm{w} \\
\text { no }\end{array}$ & $\begin{array}{l}10 \text { YYR } / 2 \\
7.5 Y R 3 / 4-4 / 5 \\
10 \text { YYR3.5/4 }\end{array}$ & $\begin{array}{l}\text { 10YR4/2 } \\
7.5 Y R 4 / 4-5 / 4 \\
10 \text { YR5 } / 4\end{array}$ & $\begin{array}{l}10 \\
75 \\
75\end{array}$ & $\begin{array}{l}\text { fiSL } \\
\text { SL } \\
\text { COSL }\end{array}$ & $\begin{array}{c}\mathrm{m}, 1 \text { med sbk } \\
2 \text { med sbk } \\
\text { sg }\end{array}$ & $\begin{array}{l}\mathrm{fr} \\
\mathrm{fr} \\
\mathrm{lo}\end{array}$ & $\begin{array}{l}\text { so,po } \\
\text { so,po } \\
\text { so,po }\end{array}$ & $\begin{array}{c}3 \mathrm{fi}, 2 \text { med, } 1 \text { co } \\
2 \text { med } \\
\text { no }\end{array}$ & $\begin{array}{l}1 \text { med tub } \\
1 \mathrm{fi} \text { tub }\end{array}$ & $\begin{array}{l}\text { no } \\
\text { no } \\
\text { no }\end{array}$ \\
\hline $\mathrm{COS}$ & $\begin{array}{l}\mathrm{A} \\
2 \mathrm{Bt} \\
2 \mathrm{Cox}\end{array}$ & $\begin{array}{l}13 \\
31 \\
85+\end{array}$ & $\begin{array}{l}c, w \\
c, w \\
\text { no }\end{array}$ & $\begin{array}{l}7.5 Y R 2 / 2 \\
10 Y R 3 / 5 \\
10 Y R 3 / 3\end{array}$ & $\begin{array}{l}7.5 Y R 3 / 2 \\
10 Y R 4 / 5 \\
10 Y R 4 / 3\end{array}$ & $\begin{array}{l}25 \\
75 \\
75\end{array}$ & $\begin{array}{l}\cos L \\
S L \\
\cos L\end{array}$ & $\begin{array}{c}\mathrm{m}, 1 \text { med sbk } \\
1 \text { med sbk } \\
\text { sg }\end{array}$ & $\begin{array}{l}f r \\
f r \\
10\end{array}$ & $\begin{array}{l}\text { so,po } \\
\text { so,po } \\
\text { so, po }\end{array}$ & $\begin{array}{l}3 \mathrm{fi}, 2 \text { med } \\
3 \text { med } \\
2 \text { med, } 2 \mathrm{fi}\end{array}$ & $\begin{array}{l}1 \text { med tub } \\
1 \text { med tub }\end{array}$ & $\begin{array}{l}\text { no } \\
\text { no } \\
\text { no }\end{array}$ \\
\hline
\end{tabular}

Satanta Peak till deposits, outer moraine, 10-12 ka

\begin{tabular}{|c|c|c|c|c|c|c|c|c|c|c|c|c|c|}
\hline $\mathrm{CO6}$ & $\begin{array}{l}\mathrm{A} \\
2 \mathrm{Bt} \\
2 \mathrm{COx}\end{array}$ & $\begin{array}{l}15 \\
38 \\
80+\end{array}$ & $\begin{array}{l}c, w \\
c, w \\
\text { no }\end{array}$ & $\begin{array}{l}7.5 Y R 2 / 2 \\
7.5 Y R 3 / 4 \\
7.5 Y R 3 / 4\end{array}$ & $\begin{array}{l}7.5 \text { YR2 } / 2 \\
7.5 \text { YR4 } \\
10 \text { Y } 5 / 4 \\
\text { 1 } 3.5\end{array}$ & $\begin{array}{l}10 \\
25 \\
75\end{array}$ & $\begin{array}{l}\mathrm{L} \\
\operatorname{coSL} \\
\operatorname{coLS}\end{array}$ & $\begin{array}{c}\mathrm{m}, 2 \text { med sbk } \\
2 \text { med } s b k \\
\mathrm{sg}\end{array}$ & $\begin{array}{l}f r \\
f r \\
f r\end{array}$ & $\begin{array}{l}\text { so,po } \\
\text { ss,po } \\
\text { so,po }\end{array}$ & $\begin{array}{c}3 \mathrm{fi}+\text { med } \\
\text { no } \\
\text { no }\end{array}$ & $\begin{array}{l}1 \text { med tub } \\
1 \mathrm{fi} \text { tub } \\
2 \mathrm{fi} \text { tub }\end{array}$ & $\begin{array}{l}\text { no } \\
\text { no } \\
\text { no }\end{array}$ \\
\hline Cu7 & $\begin{array}{l}A \\
2 A B \\
2 B W \\
2 C o x\end{array}$ & $\begin{array}{l}11 \\
16 \\
41 \\
80+\end{array}$ & $\begin{array}{l}c, w \\
c, w \\
c, w \\
\text { no }\end{array}$ & $\begin{array}{l}10 Y R 2 / 2 \\
10 Y R 2 / 3 \\
10 Y R 3.5 / 4 \\
2.5 Y 3 / 3\end{array}$ & $\begin{array}{l}10 Y R 2 / 2 \\
10 Y R 3 / 3 \\
10 Y R 5.5 / 4 \\
2.5 Y 5 / 3\end{array}$ & $\begin{array}{l}10 \\
25 \\
25 \\
50\end{array}$ & $\begin{array}{l}\text { fiSL } \\
\text { SL } \\
\text { SL } \\
\text { SL }\end{array}$ & $\begin{array}{l}\mathrm{m}, 1 \text { med sbk } \\
1 \text { med sbk } \\
2 \text { med } s b k \\
1 \text { med } s b k\end{array}$ & $\begin{array}{l}f r \\
f r \\
f r \\
f r\end{array}$ & $\begin{array}{l}\text { so,po } \\
\text { so,po } \\
\text { ss, po } \\
\text { ss,po }\end{array}$ & $\begin{array}{l}2 \text { med, } 1 \mathrm{fi} \\
2 \text { med, } 1 \mathrm{fi} \\
2 \text { med, } 2 \text { fi } \\
\quad 1 \mathrm{fi}\end{array}$ & $\begin{array}{l}1 \text { med tub } \\
1 \text { med tub } \\
1 \text { fi tub } \\
2 \text { fi tub }\end{array}$ & $\begin{array}{l}\text { no } \\
\text { no } \\
\text { no } \\
\text { no }\end{array}$ \\
\hline C08 & $\begin{array}{l}\text { A } \\
2 B W \\
2 \mathrm{Cox}\end{array}$ & $\begin{array}{c}9 \\
25 \\
85+\end{array}$ & $\begin{array}{l}c, w \\
g, w \\
\text { no }\end{array}$ & $\begin{array}{l}7.5 Y R 2 / 2 \\
10 Y R 3 / 4 \\
5 Y 4.5 / 3\end{array}$ & $\begin{array}{l}7.5 \text { YR3/2 } \\
10 \text { YR5/4 } \\
5 Y 6 / 3\end{array}$ & $\begin{array}{l}10 \\
25 \\
75\end{array}$ & $\begin{array}{l}\mathrm{L} \\
\mathrm{SL} \\
\operatorname{cosL}\end{array}$ & $\begin{array}{l}2 \text { med sbk } \\
2 \text { med sbk } \\
1 \text { fi abk }\end{array}$ & $\begin{array}{l}f r \\
f r \\
10\end{array}$ & $\begin{array}{l}\text { so,po } \\
\text { so,po } \\
\text { so,po }\end{array}$ & $\begin{array}{c}2 \text { med, } 2 \text { fi } \\
2 \text { med, } 2 \text { fi } \\
1 f i\end{array}$ & $\begin{array}{l}1 \text { med tub } \\
1 \text { fi tub } \\
1 \text { fi tub }\end{array}$ & $\begin{array}{l}\text { no } \\
\text { no } \\
\text { no }\end{array}$ \\
\hline
\end{tabular}

${ }_{2}^{1}$ Soil-profile sites are shown on figure 2 .

Lower horizon boundary is given in two parts: (1) distinctness a, abrupt; c, clear; g, gradual, d, diffuse; (2) topography: s, smooth; w, 3 wavy.

${ }_{4}^{3}$ Color is the Munsell color of the fraction less than $2 \mathrm{~mm}$ in size.

${ }_{5}^{4}$ Percentage of material larger than $2 \mathrm{~mm}$ in size is based on visual estimates.

${ }^{5}$ Texture of the material less than $2 \mathrm{~mm}$ in size is based on sieve and pipette analyses: co, coarse; fi, fine; L, loam; LS, loamy sand; SL, sandy loam; S, sand.

6 Ecept for massive $(\mathrm{m})$ and single grain (sg), structure is given in three parts: (1) grade: 1, weak; 2, moderate; (2) size: fi, fine; med, 7 medium; (3) type: sbk, subangular blocky; abk, angular blocky.

7 Moist consistence is either loose (lo) or friable $(f r)$. Wet consistence is given in two parts: (1) stickiness: so, non-sticky; ss, slightly sticky; (2) plasticity: po, non-plastic.

8 Data for roots are given in two parts: (1) abundance: 1, few; 2, common; 3, many; (2) size: fi, fine; med, medium; co, coarse.

9 Data for pores are given in three parts: (1) abundance: 1, few; 2, common; (2) size: fi, fine; med, medium; (3) shape: tub, tuhular. 
[na, sample not analyzed; nd, not determined. Analysts: A. Busacca, P. Janitsky, R. Meixner under M. Singer, University of California, Davis, and R. Kihl, University of Colorado]

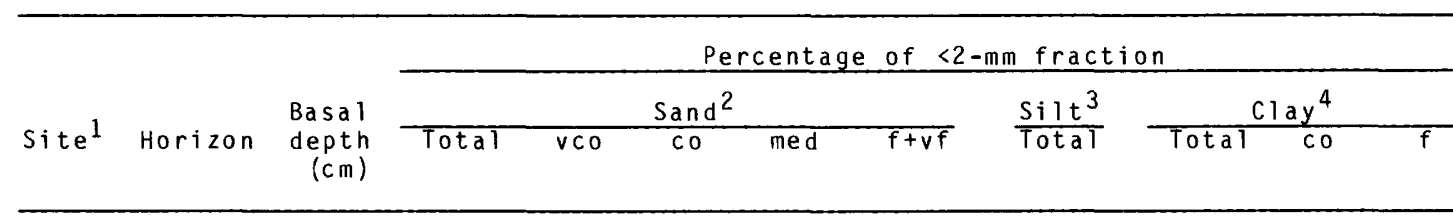

\begin{tabular}{|c|c|c|c|c|c|c|c|c|c|c|c|}
\hline & & & Ganr & tt $\mathrm{Pe}$ & $k+i 11$ & deposi & 0.1 & $.35 \mathrm{ka}$ & & & \\
\hline \multirow[t]{2}{*}{$\mathrm{CO} 2$} & $\begin{array}{l}\text { A } \\
\mathrm{Cox} \\
\mathrm{Cu}\end{array}$ & $\begin{array}{c}0.5 \\
3 \\
18+\end{array}$ & $\begin{array}{l}82.2 \\
85.6 \\
69.2\end{array}$ & $\begin{array}{l}19.1 \\
37.7 \\
19.6\end{array}$ & $\begin{array}{l}14.6 \\
20.3 \\
14.1\end{array}$ & $\begin{array}{r}12.0 \\
9.3 \\
9.1\end{array}$ & $\begin{array}{l}36.5 \\
18.3 \\
26.8\end{array}$ & $\begin{array}{r}10.9 \\
8.3 \\
20.0\end{array}$ & $\begin{array}{r}6.9 \\
6.1 \\
10.4\end{array}$ & $\begin{array}{l}3.7 \\
3.5 \\
4.3\end{array}$ & $\begin{array}{l}3.2 \\
2.6 \\
6.1\end{array}$ \\
\hline & \multicolumn{11}{|c|}{ Audubon rock-glacier deposits, $0.95-2.4 \mathrm{ka}$} \\
\hline \multirow[t]{2}{*}{$\mathrm{CO} 1$} & $\begin{array}{l}A \\
A C \\
C o x\end{array}$ & $\begin{array}{r}7 \\
27 \\
75\end{array}$ & $\begin{array}{l}80.7 \\
82.6 \\
85.0\end{array}$ & $\begin{array}{l}18.5 \\
21.1 \\
32.1\end{array}$ & $\begin{array}{l}14.2 \\
18.1 \\
18.0\end{array}$ & $\begin{array}{l}11.1 \\
11.8 \\
10.2\end{array}$ & $\begin{array}{l}36.9 \\
31.6 \\
24.7\end{array}$ & $\begin{array}{r}11.9 \\
10.5 \\
7.8\end{array}$ & $\begin{array}{l}7.4 \\
6.9 \\
7.2\end{array}$ & $\begin{array}{l}3.0 \\
3.4 \\
4.2\end{array}$ & $\begin{array}{l}4.4 \\
3.5 \\
3.0\end{array}$ \\
\hline & \multicolumn{11}{|c|}{ Lakes rock-glacier deposit, $3-5.2 \mathrm{ka}$} \\
\hline $\mathrm{CO3}$ & $\begin{array}{l}A \\
2 A \\
2 B W \\
2 C o x\end{array}$ & $\begin{array}{l}12 \\
24 \\
49 \\
58+\end{array}$ & $\begin{array}{l}74.4 \\
74.9 \\
80.8 \\
71.7\end{array}$ & $\begin{array}{l}14.4 \\
14.3 \\
20.5 \\
13.9\end{array}$ & $\begin{array}{l}14.8 \\
16.4 \\
19.7 \\
15.8\end{array}$ & $\begin{array}{l}10.4 \\
11.3 \\
12.0 \\
10.8\end{array}$ & $\begin{array}{l}34.8 \\
32.8 \\
28.5 \\
31.2\end{array}$ & $\begin{array}{l}15.0 \\
15.0 \\
11.3 \\
20.4\end{array}$ & $\begin{array}{r}10.6 \\
10.1 \\
7.9 \\
7.9\end{array}$ & $\begin{array}{l}3.9 \\
4.2 \\
4.5 \\
4.7\end{array}$ & $\begin{array}{l}6.7 \\
5.9 \\
3.4 \\
3.2\end{array}$ \\
\hline
\end{tabular}

Satanta Peak till deposits, inner moraine, $10-12 \mathrm{ka}$

\begin{tabular}{rlllrrrrrrrr}
\hline C04 & A & 14 & 62.2 & 5.7 & 6.6 & 6.0 & 43.9 & 28.6 & 9.2 & 1.6 & 7.6 \\
& 2Bt & 38 & 60.1 & 13.5 & 12.8 & 8.4 & 25.4 & 25.8 & 14.1 & 4.1 & 10.0 \\
& 2BC & $62+$ & 86.7 & 22.3 & 16.9 & 10.0 & 27.5 & 6.2 & 7.1 & 3.0 & 4.1 \\
C05 & A & 13 & 61.7 & 21.5 & 13.7 & 7.2 & 19.3 & 28.8 & 9.5 & 1.5 & 8.0 \\
& 2Bt & 31 & 63.6 & 17.3 & 12.6 & 8.3 & 25.4 & 26.3 & 10.1 & 1.3 & 8.8 \\
& 2Cox & $85+$ & 75.1 & 20.9 & 15.5 & 10.1 & 28.6 & 18.0 & 6.9 & 2.3 & 4.6 \\
\hline
\end{tabular}

Satanta Peak till deposits, outer moraine, 10-12 ka

\begin{tabular}{|c|c|c|c|c|c|c|c|c|c|c|c|}
\hline $\mathrm{CO} 6$ & $\begin{array}{l}\text { A } \\
2 B t \\
2 \mathrm{Cox}\end{array}$ & $\begin{array}{l}15 \\
38 \\
80+\end{array}$ & $\begin{array}{l}53.1 \\
66.8 \\
86.3\end{array}$ & $\begin{array}{l}17.9 \\
17.5 \\
21.6\end{array}$ & $\begin{array}{l}12.6 \\
14.5 \\
21.3\end{array}$ & $\begin{array}{r}6.7 \\
9.5 \\
15.5\end{array}$ & $\begin{array}{l}16.2 \\
25.3 \\
27.9\end{array}$ & $\begin{array}{l}33.0 \\
24.1 \\
10.7\end{array}$ & $\begin{array}{r}13.9 \\
9.1 \\
3.0\end{array}$ & $\begin{array}{l}7.0 \\
2.2 \\
1.1\end{array}$ & $\begin{array}{l}6.9 \\
6.9 \\
1.9\end{array}$ \\
\hline $\mathrm{CO} 7$ & $\begin{array}{l}A \\
2 A B \\
2 B W \\
2 C o x\end{array}$ & $\begin{array}{l}11 \\
16 \\
41 \\
80+\end{array}$ & $\begin{array}{c}71.5 \\
\text { na } \\
64.8 \\
67.7\end{array}$ & $\begin{array}{c}14.7 \\
\text { na } \\
13.6 \\
15.1\end{array}$ & $\begin{array}{c}14.4 \\
n a \\
12.6 \\
12.6\end{array}$ & $\begin{array}{l}8.2 \\
\mathrm{na} \\
9.2 \\
9.5\end{array}$ & $\begin{array}{c}34.2 \\
\text { na } \\
29.4 \\
30.5\end{array}$ & $\begin{array}{c}21.7 \\
\text { na } \\
25.9 \\
25.2\end{array}$ & $\begin{array}{l}6.8 \\
\text { na } \\
9.3 \\
7.1\end{array}$ & $\begin{array}{r}2.0 \\
n a \\
3.1 \\
3.0\end{array}$ & $\begin{array}{l}4.8 \\
\text { na } \\
6.2 \\
4.1\end{array}$ \\
\hline $\cos 8^{5}$ & $\begin{array}{l}A \\
2 B W \\
2 C o x\end{array}$ & $\begin{array}{l}9 \\
25 \\
85+\end{array}$ & $\begin{array}{l}69.2 \\
74.1 \\
74.3\end{array}$ & $\begin{array}{l}20.6 \\
20.0 \\
16.5\end{array}$ & $\begin{array}{l}18.9 \\
16.6 \\
15.4\end{array}$ & $\begin{array}{r}8.3 \\
10.7 \\
10.0\end{array}$ & $\begin{array}{l}\text { nd } \\
26.8 \\
n d\end{array}$ & $\begin{array}{l}22.5 \\
20.6 \\
18.4\end{array}$ & $\begin{array}{l}8.4 \\
5.3 \\
7.4\end{array}$ & $\begin{array}{l}0.5 \\
2.6 \\
4.0\end{array}$ & $\begin{array}{l}7.9 \\
2.7 \\
3.4\end{array}$ \\
\hline
\end{tabular}

1 soil-profile sites are shown on figure 2 .

2 Size ranges of the sand fraction are: total (2-0.05 mm); vco, very coarse (2-1 mm); co, coarse $(1-0.5 \mathrm{~mm})$; med, medium $(0.5-0.25 \mathrm{~mm})$; $f+v f$, fine and very fine (0.25$0.05 \mathrm{~mm}$ ).

${ }^{3} \mathrm{Silt}$ is 0.05 to $0.002 \mathrm{~mm}(50$ to $2 \mu \mathrm{m})$ in size.

4 Size ranges of the clay fraction are: total $(<2 \mu \mathrm{m})$; co, coarse $(2-1 \mu \mathrm{m})$; f, fine ( $<1 \mu \mathrm{m})$.

5 Analyzed by $R$. Kihl, University of Colorado. 


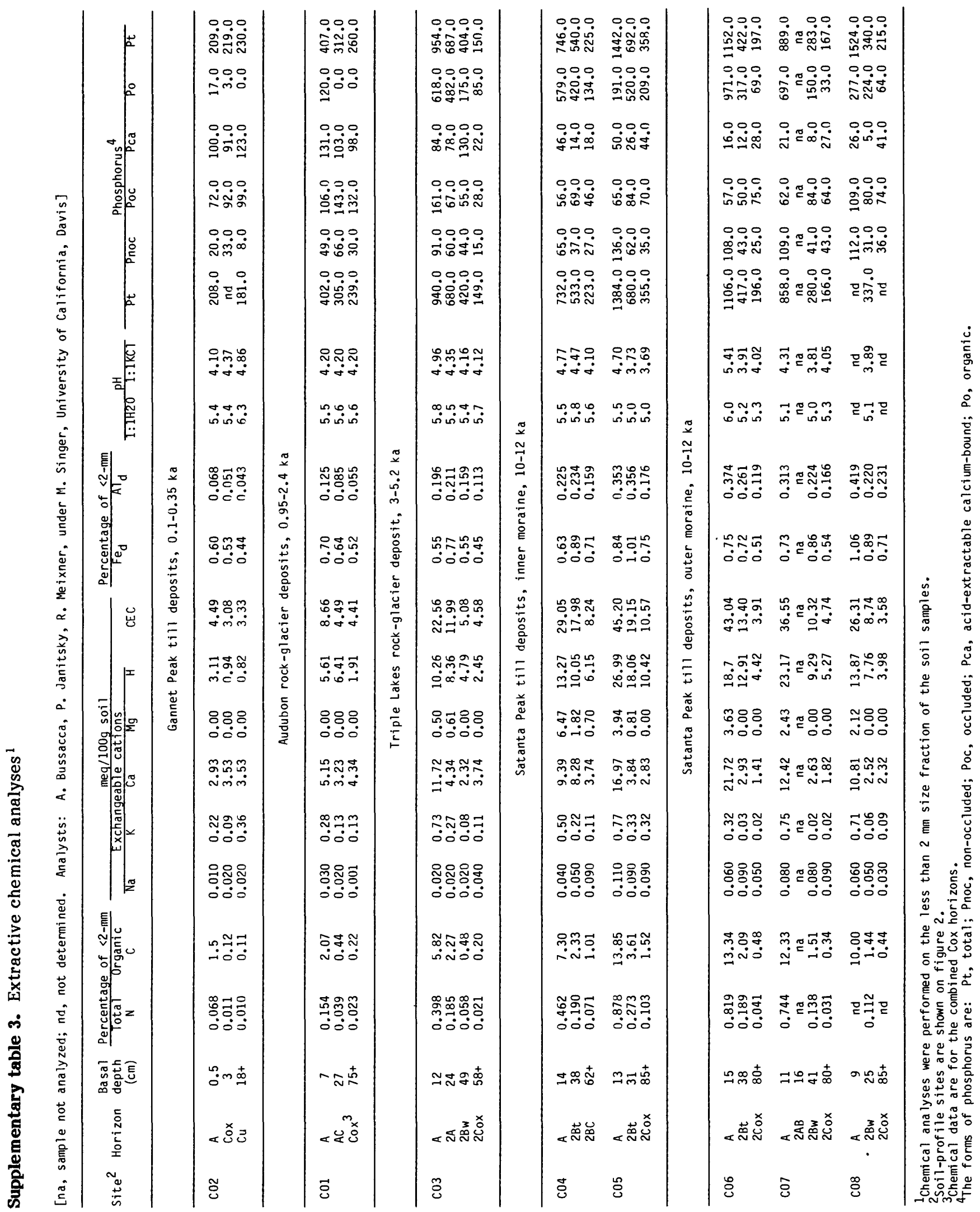


Supplementary table 4. Clay mineralogy

[Relative abundances of clay minerals based on peak height: $n$, none detected; + , minor amount; ++, moderate amount; +++, major amount; ++++, dominant amount. na, sample not analyzed. Analysts: A. Busacca, P. Janitsky, R. Meixner, under M. Singer, University of California, Davis]

Site $^{1}$ Horizon $\begin{gathered}\text { Basal } \\ \text { depth } \\ (\mathrm{cm})\end{gathered}$ Chlorite Kaolinite Smectite Mica Vermiculite ${ }^{2}$ Interstratified $^{3}$

Gannett Peak till deposits, 0.1-0.35 ka

\begin{tabular}{llllllllll}
\hline C02 & A & 0.5 & ++ & +++ & ++ & +++ & + & & $n$ \\
& Cox & 3 & na & na & na & na & na & na \\
& Cu & $18+$ & ++ & ++++ & ++ & ++++ & + & $n$ \\
\hline
\end{tabular}

Audubon rock-glacier deposits, 0.95-2.4 ka

\begin{tabular}{llllllllll}
\hline C01 & A & 7 & + & ++++ & ++++ & ++ & & & \\
& AC & 27 & + & +++ & ++++ & ++ & $n$ & $n$ \\
& Cox & 47 & + & +++ & ++++ & ++ & $n$ & $n$ \\
& Cox & $75+$ & + & +++ & ++++ & ++ & $n$ & $n$ \\
\end{tabular}

Triple Lakes rock-glacier deposit, 3-5.2 ka

\begin{tabular}{llllllllll}
\hline C03 & A & 12 & + & ++ & & +++ & ++ & $n$ & $n$ \\
& $2 \mathrm{~A}$ & 24 & + & +++ & +++ & ++ & $n$ & $n$ & + \\
& $2 \mathrm{BW}$ & 29 & + & +++ & ++++ & ++ & $\mathrm{n}$ & $\mathrm{n}$ \\
& 2Cox & $58+$ & + & ++++ & ++++ & ++ & $\mathrm{n}$ & & $\mathrm{n}$ \\
\hline
\end{tabular}

Satanta Peak till deposits, inner moraine, 10-12 ka

\begin{tabular}{|c|c|c|c|c|c|c|c|c|}
\hline \multirow[t]{3}{*}{$\mathrm{CO} 4$} & A & 14 & + & ++ & +++ & ++ & $n$ & $n$ \\
\hline & $2 \mathrm{Bt}$ & 38 & + & +++ & ++++ & + & $n$ & + \\
\hline & $2 \mathrm{BC}$ & $62+$ & + & ++ & +++ & + & $n$ & + \\
\hline \multirow[t]{3}{*}{ C05 } & A & 13 & + & ++ & ++ & ++ & $n$ & $n$ \\
\hline & $2 \mathrm{Bt}$ & 31 & + & ++ & ++ & + & $n$ & + \\
\hline & $2 \operatorname{Cox}$ & $85+$ & + & ++ & ++ & + & $n$ & $n$ \\
\hline
\end{tabular}

Satanta Peak till deposits, outer moraine, 10-12 ka

\begin{tabular}{|c|c|c|c|c|c|c|c|c|}
\hline \multirow[t]{3}{*}{ C06 } & A & 15 & + & ++ & ++ & + & $n$ & + \\
\hline & $2 \mathrm{Bt}$ & 38 & + & ++ & ++++ & + & $n$ & + \\
\hline & $2 \operatorname{Cox}$ & $80+$ & + & ++ & ++ & + & $n$ & + \\
\hline \multirow[t]{3}{*}{$\mathrm{CO} 7$} & $\begin{array}{l}A \text { and } \\
2 A B\end{array}$ & 16 & + & ++ & ++ & + & $n$ & $n$ \\
\hline & $2 \mathrm{BW}$ & 41 & + & ++ & ++ & + & $n$ & + \\
\hline & $2 \operatorname{Cox}$ & $80+$ & + & ++ & + & + & $n$ & + \\
\hline \multirow[t]{3}{*}{ C08 } & A & 9 & + & ++ & +++ & ++ & $n$ & $n$ \\
\hline & $2 B w$ & 25 & + & ++ & ++ & + & $n$ & + \\
\hline & $2 \operatorname{Cox}$ & $85+$ & + & +++ & + & ++ & $n$ & + \\
\hline
\end{tabular}

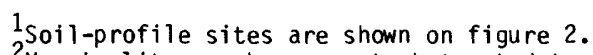

2 Vermiculite may be present, but not detectable in some samples; however, most samples showed no increase in intensity of the 1-nm peak after saturation with KCl.

3 Interstratified clay minerals are chiefly regularly interstratified mica-chlorite; some interstratified mica-vermiculite may also be present. 
Supplementary table 5. Total chemical analyses of the soils (less than $0.05 \mathrm{~mm}$ fraction) determined by X-ray fluorescence spectroscopy

[na, sample not analyzed; nd, not determined, units in weight percent. Analysts: J. Baker, J. Taggart, J.S. Wahlberg, U.S. Geological Survey, Menlo Park]

\begin{tabular}{|c|c|c|c|c|c|c|c|c|c|c|c|c|}
\hline Site ${ }^{1}$ & Horizon & $\begin{array}{r}\text { Basal } \\
\text { depth } \\
(\mathrm{cm})\end{array}$ & $\mathrm{SiO}_{2}$ & $\mathrm{Al}_{2} \mathrm{O}_{3}$ & $\mathrm{Fe}_{2} \mathrm{O}_{3}$ & $\mathrm{MgO}$ & $\mathrm{CaO}$ & $\mathrm{Na}_{2} \mathrm{O}$ & $\mathrm{K}_{2} \mathrm{O}$ & $\mathrm{TiO}_{2}$ & $\mathrm{P}_{2} \mathrm{O}_{5}$ & MnO \\
\hline \multicolumn{13}{|c|}{ Gannett Peak till deposits, $0.1-0.35 \mathrm{ka}$} \\
\hline $\mathrm{CO2}$ & $\begin{array}{l}\text { A } \\
\mathrm{Cox} \\
\mathrm{Cu}\end{array}$ & $\begin{array}{c}0.5 \\
3 \\
18+\end{array}$ & $\begin{array}{c}53.40 \\
\mathrm{na} \\
51.80\end{array}$ & $\begin{array}{c}23.60 \\
\text { na } \\
26.80\end{array}$ & $\begin{array}{c}8.850 \\
\mathrm{na} \\
8.350\end{array}$ & $\begin{array}{c}2.20 \\
\mathrm{na} \\
3.10\end{array}$ & $\begin{array}{c}0.650 \\
\text { na } \\
0.570\end{array}$ & $\begin{array}{c}0.90 \\
\text { na } \\
0.90\end{array}$ & $\begin{array}{c}2.94 \\
\mathrm{na} \\
3.83\end{array}$ & $\begin{array}{c}0.82 \\
\text { na } \\
0.90\end{array}$ & $\begin{array}{r}0.1 \\
\text { na } \\
0.1\end{array}$ & $\begin{array}{c}0.06 \\
\text { na } \\
0.09\end{array}$ \\
\hline \multicolumn{13}{|c|}{ Audubon rock-glacier deposits, 0.95-2.4 ka } \\
\hline $\mathrm{CO1}$ & $\begin{array}{l}A \\
A C \\
\text { Cox } \\
\text { Cox }\end{array}$ & $\begin{array}{c}7 \\
27 \\
47 \\
75+\end{array}$ & $\begin{array}{l}54.40 \\
53.30 \\
52.50 \\
53.20\end{array}$ & $\begin{array}{l}21.10 \\
23.80 \\
26.90 \\
24.20\end{array}$ & $\begin{array}{l}6.060 \\
6.620 \\
6.930 \\
8.940\end{array}$ & $\begin{array}{l}1.80 \\
2.00 \\
2.00 \\
2.20\end{array}$ & $\begin{array}{l}0.690 \\
0.590 \\
0.510 \\
0.510\end{array}$ & $\begin{array}{l}0.80 \\
0.80 \\
0.80 \\
0.90\end{array}$ & $\begin{array}{l}2.71 \\
2.90 \\
3.06 \\
3.31\end{array}$ & $\begin{array}{l}0.71 \\
0.71 \\
0.69 \\
0.85\end{array}$ & $\begin{array}{l}0.2 \\
0.2 \\
0.1 \\
0.1\end{array}$ & $\begin{array}{l}0.08 \\
0.10 \\
0.09 \\
0.08\end{array}$ \\
\hline
\end{tabular}

Triple Lakes rock-glacier deposit, 3-5.2 ka

\begin{tabular}{|c|c|c|c|c|c|c|c|c|c|c|c|c|}
\hline $\mathrm{CO3}$ & $\begin{array}{l}A \\
2 A \\
2 B w \\
2 C o x\end{array}$ & $\begin{array}{l}12 \\
24 \\
49 \\
58+\end{array}$ & $\begin{array}{c}\text { na } \\
50.70 \\
56.20 \\
47.00\end{array}$ & $\begin{array}{c}\text { na } \\
18.90 \\
20.30 \\
21.60\end{array}$ & $\begin{array}{c}\text { na } \\
5.750 \\
6.940 \\
8.810\end{array}$ & $\begin{array}{c}\mathrm{na} \\
1.80 \\
1.90 \\
2.20\end{array}$ & $\begin{array}{c}\text { na } \\
0.690 \\
0.660 \\
0.480\end{array}$ & $\begin{array}{c}\text { na } \\
0.90 \\
1.10 \\
0.80\end{array}$ & $\begin{array}{c}\mathrm{na} \\
2.53 \\
2.84 \\
3.19\end{array}$ & $\begin{array}{c}\text { na } \\
0.71 \\
0.81 \\
1.11\end{array}$ & $\begin{array}{l}\text { na } \\
0.5 \\
0.2 \\
0.2\end{array}$ & $\begin{array}{c}\text { na } \\
0.08 \\
0.09 \\
0.05\end{array}$ \\
\hline
\end{tabular}

Satanta Peak till deposits, inner moraine, 10-12 ka

\begin{tabular}{llllccccccccc}
\hline C04 & A & 14 & 53.40 & 16.40 & 5.290 & 1.40 & 1.060 & 1.00 & 2.44 & 0.64 & 0.3 & 0.06 \\
& 2Bt & 38 & 55.30 & 18.00 & 5.600 & 1.50 & 0.680 & 0.80 & 2.35 & 0.87 & 0.3 & 0.03 \\
& 2BC & $62+$ & 47.50 & 21.90 & 8.580 & 2.00 & 0.180 & 0.70 & 2.11 & 0.79 & 0.2 & 0.04 \\
C05 & A & 13 & na & na & na & na & na & na & na & na & na & na \\
& 2Bt & 31 & 46.90 & 19.00 & 6.970 & 1.60 & 0.440 & 0.80 & 2.54 & 0.93 & 0.3 & 0.04 \\
& 2Cox & $85+$ & 52.70 & 27.40 & 6.020 & 2.30 & 0.440 & 0.80 & 3.03 & 0.63 & 0.1 & 0.09 \\
\hline
\end{tabular}

Satanta Peak till deposits, outer moraine, 10-12 ka

\begin{tabular}{|c|c|c|c|c|c|c|c|c|c|c|c|c|}
\hline C06 & $\begin{array}{l}A \\
2 B t \\
2 C o x\end{array}$ & $\begin{array}{l}15 \\
38 \\
80+\end{array}$ & $\begin{array}{c}49.00 \\
54.60 \\
\text { na }\end{array}$ & $\begin{array}{c}11.90 \\
18.00 \\
\text { na }\end{array}$ & $\begin{array}{c}3.880 \\
5.250 \\
\text { na }\end{array}$ & $\begin{array}{c}1.30 \\
1.30 \\
\text { na }\end{array}$ & $\begin{array}{c}1.320 \\
0.410 \\
\mathrm{na}\end{array}$ & $\begin{array}{c}1.00 \\
0.80 \\
\text { na }\end{array}$ & $\begin{array}{c}2.19 \\
2.32 \\
\text { na }\end{array}$ & $\begin{array}{c}0.61 \\
0.82 \\
\text { na }\end{array}$ & $\begin{array}{r}0.4 \\
0.2 \\
\text { na }\end{array}$ & $\begin{array}{c}0.05 \\
0.04 \\
\text { na }\end{array}$ \\
\hline $\mathrm{CO}$ & $\begin{array}{l}A \\
2 A B \\
2 B w \\
2 C o x\end{array}$ & $\begin{array}{l}11 \\
16 \\
41 \\
80+\end{array}$ & $\begin{array}{c}\text { na } \\
\text { na } \\
49.80 \\
52.60\end{array}$ & $\begin{array}{c}n a \\
n a \\
22.30 \\
24.40\end{array}$ & $\begin{array}{c}\text { na } \\
\text { na } \\
8.310 \\
8.380\end{array}$ & $\begin{array}{c}\text { na } \\
\text { na } \\
2.00 \\
2.40\end{array}$ & $\begin{array}{c}\text { na } \\
\text { na } \\
0.390 \\
0.350\end{array}$ & $\begin{array}{c}\text { na } \\
\text { na } \\
0.80 \\
0.80\end{array}$ & $\begin{array}{c}\text { na } \\
\text { na } \\
2.98 \\
3.57\end{array}$ & $\begin{array}{c}\text { na } \\
\text { na } \\
0.85 \\
0.90\end{array}$ & $\begin{array}{r}\text { na } \\
\text { na } \\
0.2 \\
0.1\end{array}$ & $\begin{array}{c}\text { na } \\
\text { na } \\
0.04 \\
0.06\end{array}$ \\
\hline $\mathrm{C08}$ & $\begin{array}{l}A \\
2 B W \\
2 C o x\end{array}$ & $\begin{array}{c}9 \\
25 \\
85+\end{array}$ & $\begin{array}{l}50.80 \\
50.20 \\
51.00\end{array}$ & $\begin{array}{l}12.80 \\
21.60 \\
24.80\end{array}$ & $\begin{array}{l}4.500 \\
8.180 \\
8.480\end{array}$ & $\begin{array}{l}1.40 \\
1.90 \\
2.40\end{array}$ & $\begin{array}{l}0.960 \\
0.450 \\
0.370\end{array}$ & $\begin{array}{l}1.00 \\
0.80 \\
0.80\end{array}$ & $\begin{array}{l}2.35 \\
2.63 \\
3.55\end{array}$ & $\begin{array}{c}\text { nd } \\
0.89 \\
0.94\end{array}$ & $\begin{array}{l}0.4 \\
0.2 \\
0.1\end{array}$ & $\begin{array}{l}0.05 \\
0.03 \\
0.05\end{array}$ \\
\hline
\end{tabular}

1 Soil-profile sites shown on figure 2. 


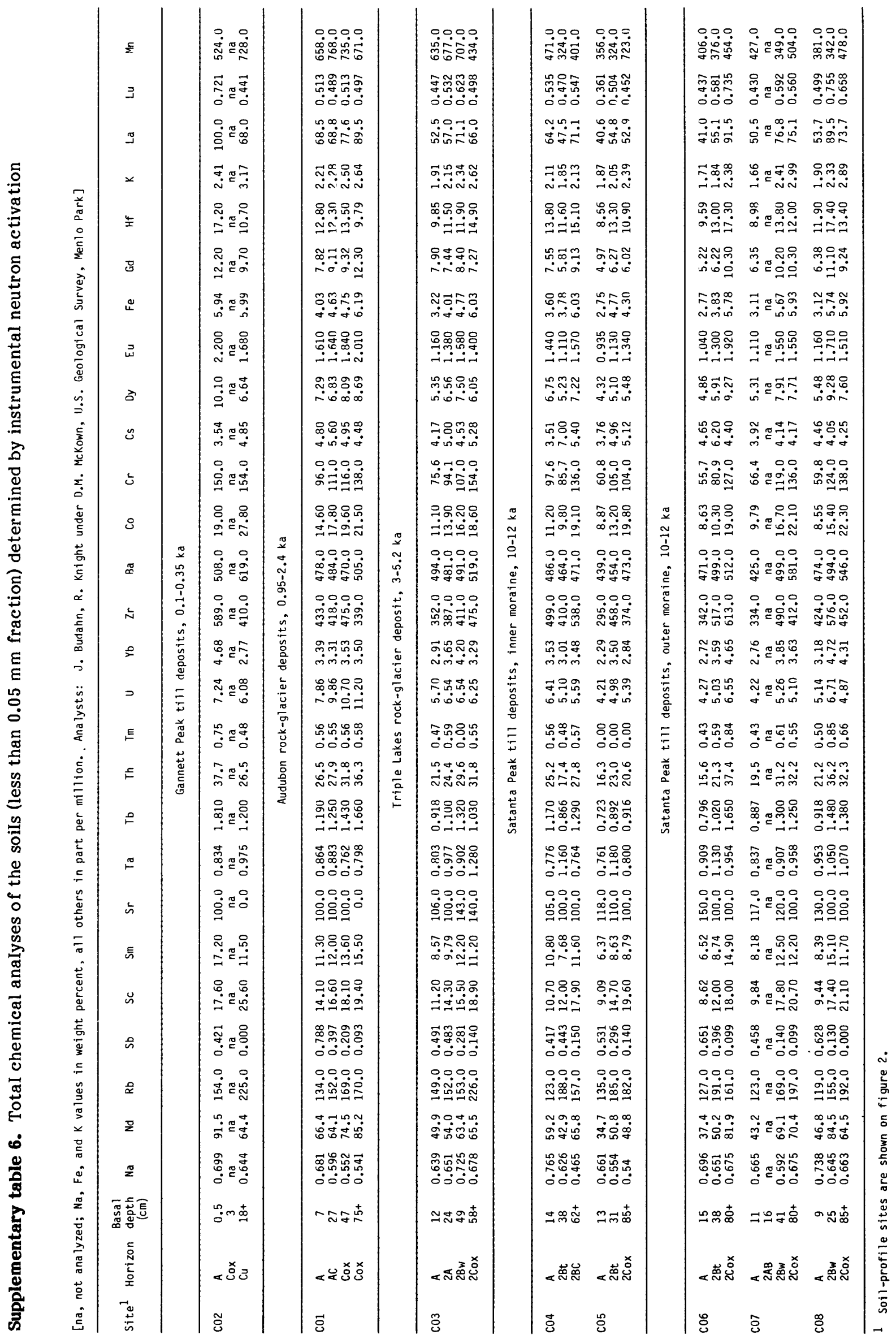


GPO 785-048/77402 



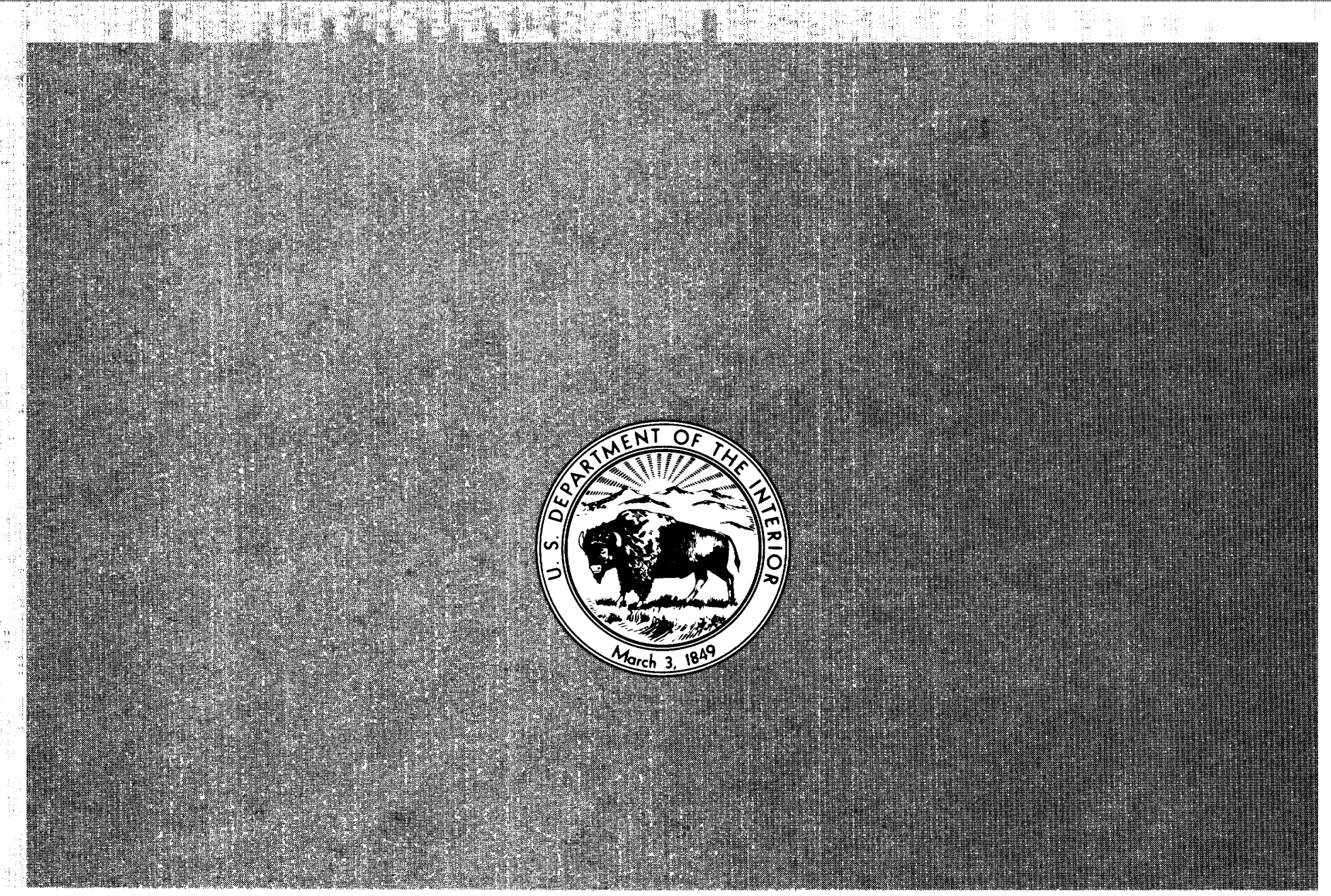

